\title{
Grace upon Grace Reflections on the Meaning of Life
}

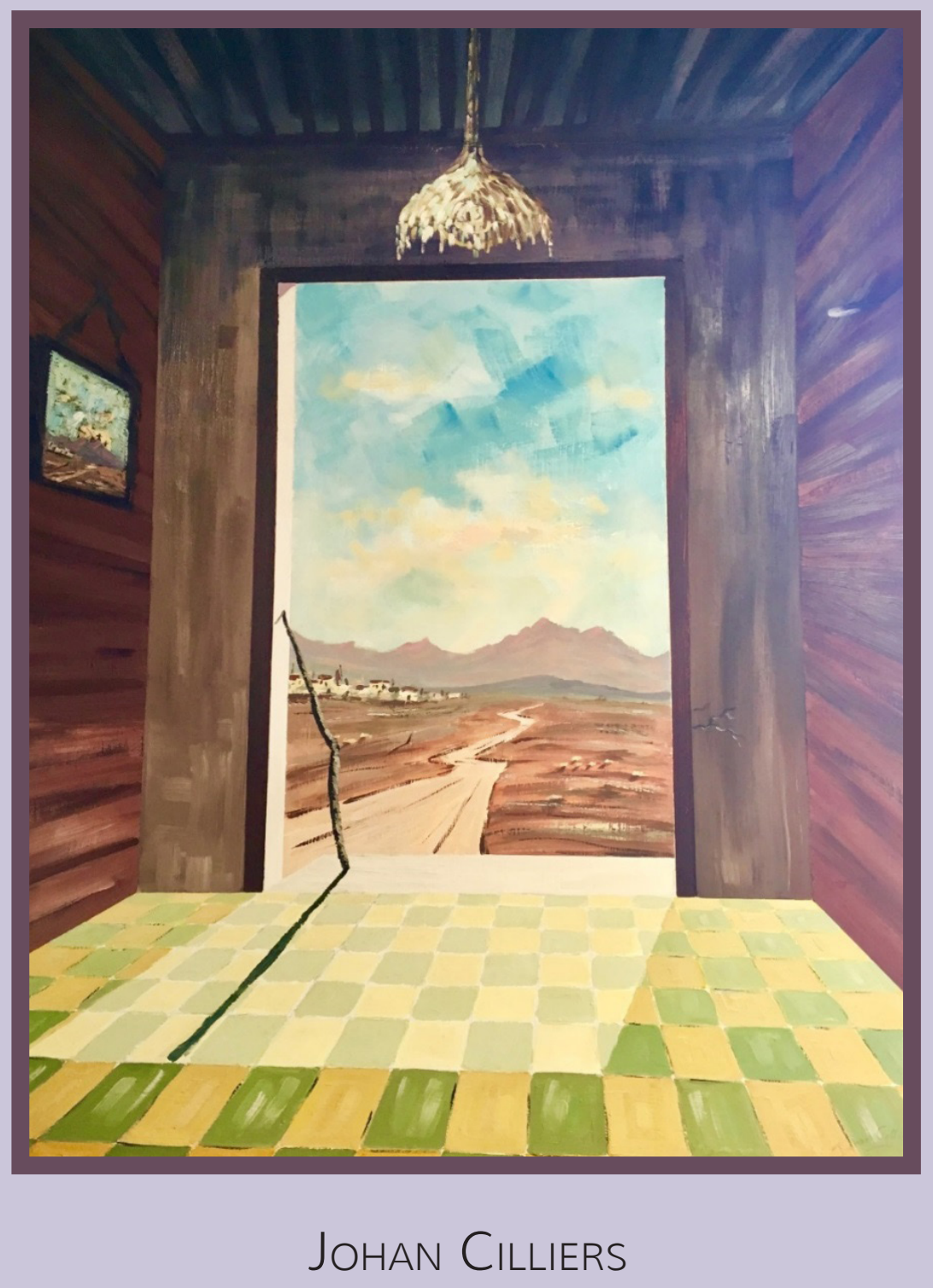


Grace upon Grace Reflections on the
Meaning of Life

Johan Cilliers 
Grace upon Grace: Reflections on the Meaning of Life

Published by African Sun Media under the SUN MeDIA imprint

All rights reserved

Copyright $(2020$ African Sun Media and Johan Cilliers

The author and the publisher have made every effort to obtain permission for and acknowledge the use of copyrighted material. Refer all enquiries to the publisher.

No part of this book may be reproduced or transmitted in any form or by any electronic, photographic or mechanical means, including photocopying and recording on record, tape or laser disk, on microfilm, via the Internet, by e-mail, or by any other information storage and retrieval system, without prior written permission by the publisher.

Views reflected in this publication are not necessarily those of the publisher.

First edition 2020

ISBN 978-1-928314-71-4

ISBN 978-1-928314-72-1 (e-book)

https://doi.org/10.18820/9781928314721

Set in Warnock Pro 10/12 pt

Cover design, typesetting and production by African Sun Media

Cover image: Into Life (2001) by Johan Cilliers

SUN MeDIA is an imprint of African Sun Media. Academic and general works are published under this imprint in print and electronic formats.

This publication can be ordered from:

orders@africansunmedia.co.za

Takealot: bit.ly/2monsfl

Google Books: bit.ly/2k1Uilm

africansunmedia.store.it.si (e-books)

Amazon Kindle: amzn.to/2ktL.pkL

Visit africansunmedia.co.za for more information. 
This book is dedicated to Elna, Karen and Jacques makers of meaning, each in their own right. 


\section{REVIEWS}

In his familiar and much-loved poetic style, Johan Cilliers takes up his pen like a walking stick, leads the way and invites his readers on a journey. On route, he explores the landscape of the meaning of life by visiting three places: where we come from, where we are going and who we are. The grace for humankind he finds in this space is well timed, given the Covid-19 pandemic, as people are now more than ever longing for meaning and in need of the comforting message of Grace upon grace. With this monograph, he completes his trilogy and, just like A Space for Grace and Timing Grace, Grace upon Grace is an important theological as well as a beautiful achievement.

Cas Wepener

Professor in Practical Theology Stellenbosch University

Grace is like an avalanche. It is overflowing, abundantly, transforming time into awe, wondering with the exclamation mark of 'amazing grace!. It is not merely costly (Dietrich Bonhoeffer) but beautiful, life-giving and a source for meaningful existence. Johan Cilliers depicts the aesthetics of grace in terms of spiritual playfulness, full of joy and festivity. The book is like a 'bricolage', sketching a 'starry-eyed gaze' before "this universe blinking in the disbelief of never-ending discoveries" (Cilliers). We are depicted as being more-than-apes - the vulnerable and fragmented species of gratitious fools - the joyful delight of wording the gospel (aesthetics of preaching). Johan addresses the pain of untimely death, and the temptation of human grief and suffering (Anfechtungen) from the gracious perspective of a "marvelous exchange" (Martin Luther): the liberating human experience of substitution - the suffering God in my place on my behalf; the playful God (Deus ludens). In this way, Johan sets the tone for a new approach to preaching: gossiping the gospel as a liturgical way of life by means of daily, humane encounters. Then we (with our fragmented identity) enter the landscape of life like living with a Karoo vision: "the beautiful order of cosmic chaos" (Cilliers). Life is like Dadaism - experienced as without value, until discovering: We are indeed valued by grace! The world is then painted in lemon, yellow, orange, purple and red because we live life as 'being-at-home'!

Daniël Louw

Professor Emeritus in Practical Theology Stellenbosch University

The hermeneutical key to understanding Johan Cilliers as friend, colleague, academic, artist and writer, one finds through developing an appreciation for the place where he grew up, namely the Karoo, also called the Moordenaarskaroo. Reflecting amidst the open skies of the Karoo on the meaning of life, he uses three different lenses: Not knowing, fully ... Knowing, fully ... Being known, fully. He developed the three 
lenses by making use of the profound utterance of the Apostle Paul, taken from the well-known verse in 1 Corinthians 13:12: "For now we see only a reflection as in a mirror; then we shall see face to face. Now I know in part; then I shall know fully, even as I am fully known." In our endeavours to know fully, we are, according to Johan, indeed like sunflowers looking away from ourselves and lifting our heads towards the sun, towards our creator, towards God. In this way, we reach our destiny, we start to flourish, and are fully known by God.

Ian Nell

Professor in Practical Theology Stellenbosch University

In this book, Johan Cilliers addresses the big questions in life: Where do we come from? What are we? Where are we going? This book is definitely not a 'self-help scheme' or a 'feel-good enterprise'. Instead, he introduces the reader to "the art of meaning-making", with fragments, different voices: biblical, his own and others', and with aesthetic expressions. The fragments place the reader into the "Karoo" that forms a metaphor for Cilliers's theological thinking, a dry and arid landscape with awesome night skies, a place where the Cross of Christ is to be found. If you ever thought about the meaning of life, read this book. Grace upon Grace is full of meaning and an excellent contribution to the art of theology.

Thomas Girmalm Senior Lecturer in Practical Theology Umeå University, Sweden

Profound and beautiful, Grace upon Grace overflows with wisdom and the art of seeking meaning in life. Written during the onset of Covid-19, Grace upon Grace offers us Scripture, theology, and art as necessary companions in the life-long process of making meaning amid life's tragedies and joys. Cilliers is a homiletician and practical theologian, pastor and scholar, teacher and preacher, spouse and father, who knows that words are never enough: we need the grace of God given in abundance, stories and scriptures infused with divine light, mind and heart, pictures and sermons that stir our imaginations and hope. Buy it now and read it again and again.

Dawn Ottoni-Wilhelm

Brightbill Professor of Preaching and Worship Bethany Theological Seminary, Richmond, Indiana, USA and former president of Societas Homiletica 


\section{CONTENTS}

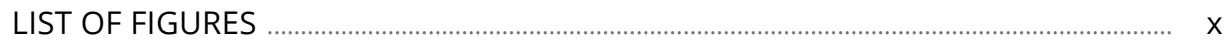

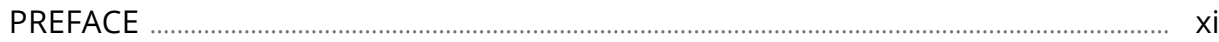

INTRODUCTION: Where do we come from? What are we? Where are we going? ... 1

Meditative Interruption .................................................................................................... 8

In Memory of Adriaan Engelbrecht (1 Corinthians 13:12)

1 GRACE: TO KNOW THAT YOU DO NOT KNOW, FULLY ......................................... 13

Meditative Interruption .................................................................................................. 32

Sense under the sun? (Ecclesiastes 1:1-11; 12:9-14)

2 GRACE: TO KNOW THAT YOU WILL KNOW, FULLY ............................................... 41

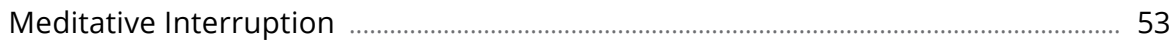

"I am making everything new!" (Revelations 21:1-8)

3 GRACE: TO KNOW THAT YOU ARE KNOWN, FULLY ............................................... 59

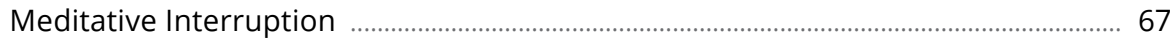

Lord, You know me (Psalm 139:1-3, 13-18)

CONCLUSION: The art of meaning-making …................................................................. 73

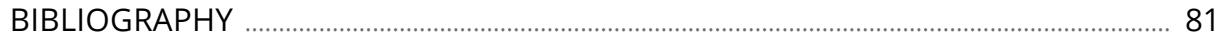




\section{LIST OF FIGURES}

1 Gauguin: Where do we come from? What are we?

Where are we going? (1897)

2 Johan Cilliers: The beautiful order of cosmic chaos (1995) ................................. 14

3 Martin Mostert: Official Chaos (2019) ........................................................................ 17

$4 \quad$ Karen Cilliers: zzzzzzzzzz ... (2002) ........................................................... 25

$5 \quad$ Marcel Duchamp: Bicycle Wheel (1951) ............................................................ 29

6 Jacques Cilliers: Speaking, silence, and truth (2005) ......................................... 31

$7 \quad$ Pablo Picasso: La Joie de Vivre (1946) ............................................................... 39

8 Johan Cilliers: Into Life (2001) ............................................................................ 48

9 Johan Cilliers: Detail: Into Life (2001) ................................................................... 50

10 Johan Cilliers: This very Body (2010) ..................................................................... 63

11 Elna Cilliers: Blanket (2019) ................................................................................. 66

12 Integration: Finding the knowledge of meaning ………………………............. 76

13 Disintegration: Losing the art of meaning ................................................................ 79 


\section{PREFACE}

This book wrote itself.

The impulse(s), to write this book, often appeared in the most curious places and times - when I walked the dog, sat outside in the garden, had a glass of (good, South African) red wine, or just before I went to bed, I scribbled down notes on random pieces of paper. The latter, of course, posed me with the challenge to decipher my handwriting the next day - not the easiest thing to do.

The point is, I could not resist the voice(s) of this book calling out to me. The impulse(s) was too persistent. She was not to be denied. I sometimes felt my finger guided by someone outside, or rather, standing beside me.

On second thought, this sounds too preposterous - perhaps it simply has to do with the fact that, while writing this book, I had (more) time to walk the dog, sit outside in the garden, drink a glass of red wine, or to search for random pieces of paper, being retired of late. Time for reflection, indeed, to ponder the meaning of life from a different angle. Time to write a book, perhaps a bit more autobiographical than most of my previous efforts? Perhaps understanding better that what is most personal is also most universal?

Of course, this book did not write itself. I did. It was my finger that wrote and moved on. I accept full responsibility for the outcome. As in the famous line:

The Moving Finger writes; and, having writ,

Moves on: nor all thy Piety nor Wit

Shall lure it back to cancel half a Line,

Nor all thy Tears wash out a Word of it. ${ }^{1}$

However, as is the case with all books being written, many fingers wrote with me. Many wise people peeped over my shoulder as I created words and sentences on my keyboard. Their wise thoughts kept on lingering in my mind, guiding my finger (indeed singular: I type with only one finger!) to form these words and sentences.

I do not have enough words and sentences to thank them. I cannot name them all. Many of them are no longer with us, at least bodily; some of them are old and ageing; some are young and vibrant and challenging, and all of them are in this book, even if not mentioned by name.

1 This line comes from Edward FitzGerald's English translation of the poem, The Rubáiyát of Omar Khayyam, 1859. 
As always, I could not write without images, which will, hopefully, also stir the imagination. Given the topic of this book, I realised once more that the search for meaning could not be undertaken without aesthetic expression. In this book, I try to stand aside, ever so often, to allow different forms of aesthetics to 'speak'.

With this in mind, I also interrupted my thinking regularly by introducing different voices, reflecting explicitly on Biblical texts - the voices of a preacher, a teacher, a visionary, and a psalmist - all of them trying to 'make sense of it all'. These meditative reflections on the meaning of life come without footnoted sources, as is the case in the rest of the book.

Although I am a homiletician, and this book is not about preaching, I hope to be forgiven if the issue of preaching does surface somewhat, here and there.

This book has not finished writing itself. Neither have I. For that, the topic is too broad and wide and deep. Too 'human'.

The finger(s) keep on writing, keep moving on. 


\section{INTRODUCTION}

\section{Where do we come from? What are we? Where are we going?}

"I am here now."

This is probably the most profound statement that any (human) being can ever make. Let us, for the moment, read it backwards:

'Now' - I have been given the gift, i.e. the grace of time, a moment, moments.

'Here' - I have been given the gift, the grace of space, spaces.

'Am' - I have been given the gift, the grace of life, existence.

'I'- I have been given the gift, the grace of being me, of individuality.

However, in saying 'I', 'I' also means 'we'.

We have been given the gift, the grace of community.

We are here now.

For me, this is 'grace, upon grace' - a phrase which I borrow, hopefully gracefully, from the somewhat ambiguous expression used by John in the prologue to his Gospel:

For from his fullness, we have all received, grace upon grace. For the law was given through Moses; grace and truth came through Jesus Christ. ${ }^{2}$

Many interpretations have been offered of this utterance, on which I will not dwell here. ${ }^{3}$ Whatever the nuance might be, for me, it indicates that grace is adequate, no, more than abundant for, and in every epoch in God's dealings with us. God's grace is like an avalanche; it keeps on flowing, and with cascading effect. There is no

$2 \quad$ John 1:16-17. The Bible. English Standard Version.

3 See the excellent and detailed discussion by Ruth B. Edwards, 1988, XAPIN ANTI XAPITO $\Sigma$ (John 1:16) Grace and the Law in the Johannine Prologue, 1-14. Some commentators interpret the key, Greek

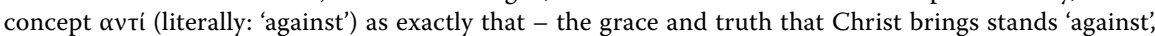
i.e. 'in place of' the law given through Moses. As in: "Out of his fullness we have all received grace in place of grace already given." Others would say that $\alpha v$ ti here means 'upon', 'in addition to', referring to the inexhaustible bounty of God's gifts, resulting in a constant stream of graces, in one blessing after another. The New Living Translation captures this thought: "From his abundance we have all received one gracious blessing after another." Some point out that, rather than choosing between synonymous and/or antithetic parallelism as pertaining to this verse, we should classify it as 'synthetic' or 'progressive'. Then the possible translation could be: "Just as the law was given through Moses, so grace and truth came through Jesus Christ." Or even: "Just as the law was given through Moses, even more so grace and truth came through Jesus Christ." 
shortage, ever - there is a fullness to it that cannot be depleted. We have all already received it - it is timeous, always, like fresh dew in the early morning. ${ }^{4}$

Indeed: God's grace has its own 'timing.'

There is grace in creation, grace in life, and grace in death.

There is grace in the past, present, and future.

There is grace for every season of our lives.

I - we - are here now - that is grace upon grace upon grace.

Of course, all the above rests upon an assumption - that grace can and has been given. That grace is not merely a religious abstraction, theological or ecclesiological jargon, or pious discourse, but a reality that more than often surprises us, overtakes us when least expected, comes to us in moments of unprecedented clarity. Does anybody say this more eloquently than General Lorens Löwenhielm, proposing a toast at the table of Babette in the classic film, Babette's Feast?

Mercy and truth have met together. Righteousness and bliss shall kiss one another. Man, in his weakness and short-sightedness, believes he must make choices in this life. He trembles at the risks he takes. We do know fear. But no. Our choice is of no importance. There comes a time when your eyes are opened. And we come to realize that mercy is infinite. We need only await it with confidence and receive it with gratitude. Mercy imposes no conditions. And lo! Everything we have chosen has been granted to us. And everything we rejected has also been granted. Yes, we even get back what we rejected. For mercy and truth are met together. And righteousness and bliss shall kiss one another. ${ }^{6}$

Mercy is infinite. Not everybody would see or articulate it in this way. Many obstacles could prevent us from taking this point of view. ${ }^{7}$ One could perhaps say that the world has, to a large extent, become graceless; that we have fallen out of grace. That we, as the human race, have become a disgrace.

In this book, I (again) articulate my conviction that we have been granted grace, upon grace. Somehow, the word 'grace' has been my companion as far back as I can remember. One of the first (academic) books I wrote, bore the somewhat disturbing title, Die Uitwissing van God op die Kansel - The Annihilation of God on the Pulpit. I wrote this book after listening to moralistic sermons, with grace (literally) written out of the picture, resulting in the annihilation of God (annihilatio Dei).

Psalm 110:3. The Bible. English Standard Version.

See Johan Cilliers, 2019, Timing Grace. Reflections on the Temporality of Preaching, Chapter 2.

The movie, Babette's Feast (1987) was adapted from a short story by the famous Danish writer Karen Blixen (1885-1962), who wrote under the pen name of Isak Dinesen.

7 See also the discussion in Chapter 3. 
I followed up this book by a book that tried to illustrate the opposite, namely the preaching of the good news of grace, titled Die Uitwysing van God op die Kansel - Pointing Towards God on the Pulpit. The trilogy was completed by a book that argued that grace does not exclude obedience but includes it (Die Genade van Gehoorsaamheid - the Grace of Obedience).

Grace did not leave me after this. She still had (and has) much to teach me - being part of the graceless and disgraceful world in which we live. So, I tried again, writing a book called, $A$ Space for Grace; and given the fact that we cannot speak about space without speaking about time, I ventured another one: Timing Grace. In this book, I contended:

The word 'grace', and variations thereof, probably represents one of the most used concepts in Christianity, perhaps even in all religions. But, what does 'grace' mean? I would say that grace is the deconstruction of the 'predictable timing' of the conditional cause-and-effect structure, through the unconditional and mostly 'unpredictable improvisation' of time that is characteristic of timing. In this sense, grace is experienced in space and time, but also transcends the categories of space and time. ${ }^{8}$

I truly thought that would be it - no more trilogies, but here it is again, knocking at my door, calling out, or rather, softly whispering, "Grace, upon grace." This whispering indeed forms a Leitmotiv throughout what follows.

How is all of this connected to the quest for the meaning of life? Briefly put, and in preliminary terms: grace surprises us, perpetually opens up new insights, new perspectives - on life, and the meaning of this life. It is indeed a gift, granted from somewhere outside of us, working inside of us, constructing and clarifying and celebrating life for us. It keeps on deconstructing the conditional cause-and-effect structures of rigid 'knowledge'.

Of course, the quest for, and the question about the meaning of life is as ancient as life itself. It has been and can be, addressed from a multitude of perspectives, for instance from anthropological, sociological, psychological, neurological, philosophical, cultural-religious, theological, cosmological, astrophysical, aesthetical stances, and many more.

The endeavours to answer this question can indeed oscillate between profound psychological contributions such as made by Victor Frankl in his classic book, Man's search for meaning, born from the experiences of unimaginable suffering in the Nazi concentration camps during the Holocaust, and the now somewhat popularised notion of logotherapy ("The meaning of life is giving meaning to life"), and more ironic and satiric answers given to this loaded question. ${ }^{9}$

$8 \quad$ Cilliers, Timing Grace, 33ff.

9 In earlier writings, I made some comments on the links between aesthetics and hope, i.e. finding meaning in life, in suffering. I wrote: "Nowhere are the connections between aesthetics and hope expressed more 
Take the version offered by Monty Python in his classic cult film, released in 1983, titled The Meaning of Life. After some scenarios, portrayed as seven stages of life, i.e. The miracle of birth; Growth and learning; Fighting each other; Middle age; Live organ transplants; The autumn years; and Death, the final scene, called The end of the film, states:

Well, it's nothing very special. Try to be nice to people, avoid eating fat, read a good book every now and then, get some walking in, and try and live together in peace and harmony with people of all creeds and nations. ${ }^{10}$

This description of the meaning of life is light-years away from the hell of the Holocaust, but you cannot argue with that, either, can you? Perhaps we should not take this serious question so seriously, that we lose out on what the question is all about, namely the meaning of life. Seriously.

There seems to be no single answer to this most profound question of our lives, I believe. However, aesthetics would be one of the most helpful spaces to enter in any endeavour to link grace with the quest for the meaning of life. ${ }^{11}$ Why? Because aesthetics constitutes the exact opposite of moralism, of rigid knowledge, of causeand-effect structures. While moralism, for instance, clamps down on immovable 'laws', aesthetics points towards options. While rigid knowledge allows no venturing across the boundaries, aesthetics says: what if? While cause-and-effect structures know only about one, inescapable outcome, aesthetics is not impressed by cul-de-sacs.

So, could life's meaning not also be found, inter alia, in pondering different options, in venturing across boundaries, or in (re)discovering ways through the dead-end streets of life? Furthermore, could this not be called 'grace'?

For me, aesthetics opens up playful spaces for expressing the inexpressible, often in a deeply personal sense, as will become evident in this book.

Let us linger for a moment - to whet the appetite - with one such perspective, taken from the world of aesthetics. During 1897, after leaving France to live in Tahiti, Paul

movingly than in the writings of Victor Frankl. He tells how the most terrible moments in Auschwitz were made bearable by sporadic aesthetic experiences: the sun shining through the trees in the wood (almost like an aquarelle by Dürer); cloud formations on the horizon; a sunset; a far-off light of a farm house in the grey morning hours. Experiences like these caused prisoners - often dying - to say yearningly and with anticipation: 'How beautiful the world can be...' On the second night that Frankl was in Auschwitz he was woken up by the sound of a violin playing a mournful tango. He thought of someone who had to celebrate her birthday in a cell block only a few hundred metres from where he was. So near, and yet so far, he thought. It was his wife. In his imagination he stood up and danced with her, and in his imaginative dancing, he filled the dark hours of the present with a hope against all hope." See Johan Cilliers, 2012, Dancing with Deity: Reimagining the Beauty of Worship, 187; see also Frankl, 1947, Ein Psycholog erlebt das Konzentrationslager, 56-60.

10 Wikiquote. 2020. Monty Python's The Meaning of Life.

11 With this, I am not romanticising the notion of aesthetics. It will, however, form a basic perspective in my own approach throughout this book. For my understanding of aesthetics, see Cilliers, Dancing with Deity, Chapter 2. 
Gauguin painted a masterpiece, which he titled Where do we come from? What are we? Where are we going?

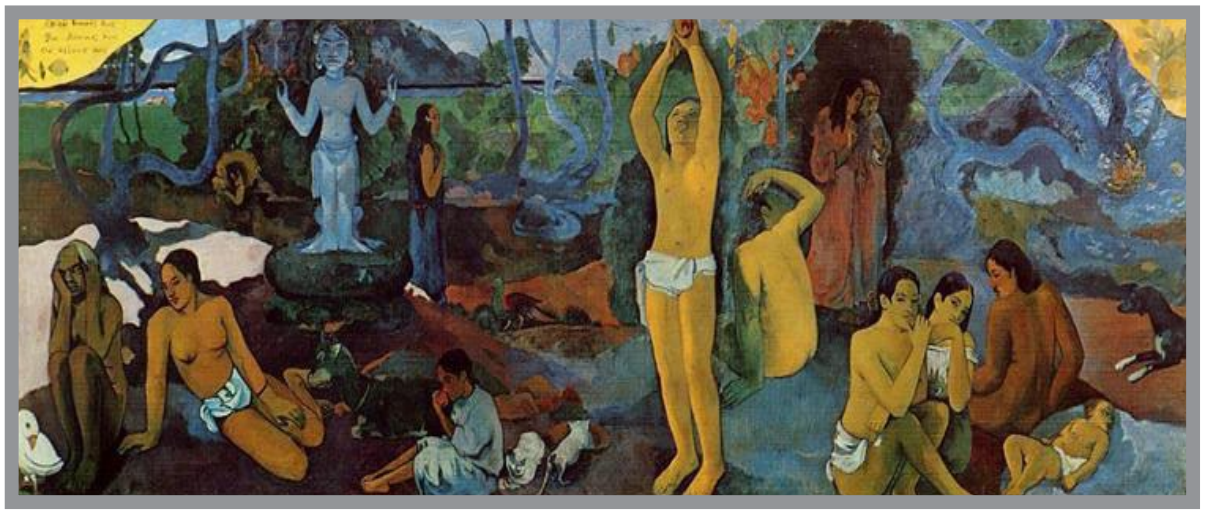

FIGURE 1: Where do we come from? What are we? Where are we going? (1897) by Paul Gauguin (Public Domain).

This title is telling, for many reasons. First, Gauguin allegedly planned to commit suicide after finishing this work, but somehow the aesthetic experience of creating the painting prevented him from doing this. ${ }^{12}$

Second, Gauguin's painting brings together on one canvas universal, human questions concerning the meaning of life. The interplay between human anxiety and the quest for tranquility is, for instance, interpreted through light and shadows, colour contrasts, and being in-and-out of perspective.

In the foreground, a human being is gathering fruit, stretching out so to speak, to touch and digest this symbol of life. Behind the outstretched figure sits a person (somewhat out of perspective), watching two others, dressed in purple, passing by. The squatting figure seems to ponder the fate of those in pilgrimage intensely.

The painting should be viewed from right to left. On the right, an infant can be seen sleeping - the beginnings of existence. On the left, an old woman is visible, awaiting death, with resignation - the end of life. All of life's activities take place between these two pictures, or states of affairs - from the cradle to the grave. The figures are in their way, posing the questions of human existence:

Where do we come from? What are we? Where are we going?

12 His own description of the aesthetic painting of this scene, is insightful: "They will say that it is careless, unfinished. It's true that it's not easy to judge one's own work, but in spite of that I believe that this canvas not only surpasses all my preceding ones, but that I shall never do anything better, or even like it. Before death [Gauguin claimed to have attempted suicide] I put into it all my energy, a passion so painful in circumstances so terrible, and my vision was so clear that all haste of execution vanishes and life surges up. It doesn't stink of models, of technique, or of pretended rules - of which I have always fought shy, though sometimes with fear." See George Shackelford, 2004, Gauguin Tahiti, Exhibition Catalogue, 168. 
Particularly interesting is the blue idol, representing 'the Beyond', in the background next to a stream in the woods - recollecting the Garden of Eden? ${ }^{13}$

There is a third reason why this painting is remarkable, given the often melancholic and cynic stance of Gauguin towards life. In a sense, the title of his painting acts as a counterpart to an earlier book by the German natural scientist Ludwig Büchner, which led to much controversy and discussion. It was published in 1869 and was titled, in part, with the exact phrase as in the title of Gauguin's painting, Der Mensch und seine Stellung in der Natur in Vergangenheit, Gegenwart und Zukunft: Woher kommen wir? Wer sind wir? Wohin gehen wir? - Humanity's place in nature, in past, present and future: Where do we come from? Who are we? Where are we going? Büchner himself had a clear answer to this age-old triad of questions:

Where do we come from? - From the apes.

Who are we? - Perfected apes.

Where are we going? - Towards the reabsorption in universal matter.

Furthermore, added to that:

What is our ideal? - A race-of-apes, more perfect than ourselves ...14

Gauguin's painting offers an alternative. The abundant fauna and flora suggest, on the one hand, that we are like the apes, indeed part and parcel of the ecological systems of life. On the other hand, although our DNA might be close to those of animals, something happened within the wiring of our brains - a code of some sorts was installed, that makes us consciously reflect on the meaning of life, and ultimately, about God, about what is 'beyond' us, making us humans unique.

In Gauguin's painting, the Indian idol points to the 'beyond', to where we are en route and indeed linked. It suggests that the cycles of birth and death, albeit real and inescapable, are not eternally fixated, but open to other dimensions of existence. ${ }^{15}$

So, where do we come from? What are we? Where are we going? These three questions, posed by Gauguin's masterpiece, could also be linked to the classic, temporal frames of past, present, and future, for instance in the work of Ludwig Büchner, referred to above.

In this book, I propose another triad, loosely linked to Gauguin's and Büchner's approaches, but also with a distinction.

13 See André Breton, Conversations: The Autobiography of Surrealism, 230-236.

14 Ludwig Büchner, 1869, Der Mensch und seine Stellung in der Natur in Vergangenheit, Gegenwart und Zukunft: Woher kommen wir? Wer sind wir? Wohin gehen wir? $33 \mathrm{ff}$.

15 Gauguin borrowed his image of the idol from an illustration of an Indian pentacle in Eliphas Lévi's, Dogme et rituel de la haute magie [Dogma and Ritual of High Magic], 1854; and, according to Lévi, the pantheistic Addha-Nari "represents Religion or Truth, terrible for the non-believers and sweet for the initiates". See the fascinating discussion in Albert Boime, 2008, Gauguin's D'où venons-nous? Que sommes-nous? Où allons-nous? Millenarianism and Necromancy in Fin-de-Siècle France, 175-176. 
The basic structure will be:

Not knowing, fully...

Knowing, fully ...

Being known, fully...

I base this on a profound utterance of the Apostle Paul, taken from the well-known 1 Corinthians 13 on faith, hope, and love:

For now we see only a reflection as in a mirror; then we shall see face to face. Now I know in part; then I shall know fully, even as I am fully known. ${ }^{16}$

May I, knowing fully (pun intended!) that these modes of knowledge and temporal frames ('now ... then') can be distinguished, but not separated, venture to 'describe' a 'graceful, aesthetical space within which the quest for meaning could take place'? It represents a preliminary attempt, to be revisited in more detail in the chapters to follow:

The quest for meaning takes place in the interplay between the negotiations of not knowing fully, the hope of knowing fully, and the good news that we are known, fully.

Alternatively, to put it in other (more 'theological' terms): the quest for meaning is nurtured in and through the intersections of hermeneutics (the art of interpretation), hope (the art of expectation), and healing (the art of being comforted).

Before we go further with this (admittedly, somewhat elaborate sounding) enterprise, let us be interrupted by a preacher, struggling to make sense of an untimely death. ${ }^{17}$

161 Corinthians 13:12.

17 I use the notion of "interruption" deliberately. Interruption has been called the shortest definition of religion, indeed a category that stands at the very heart of the Christian faith. Cf. the insightful articles by Lieven Boeve, "The shortest definition of religion", 1, 2, and 3, in The Pastoral Review, 2012, Volume 5, issues 3, 4, and 5, resp. pages 4-9; 4-9; and 18-25. This notion could be understood on at least three levels: first, as the cultural interruption of Christian identity, i.e. as the fact that Christian traditions are constantly being challenged by culture (and could consequently either adapt to, or oppose, or re-contextualise themselves in the light of these challenges); second, as the interruption by the so-called "other" - the marginalised, the powerless, the weak and vulnerable - an interruption that carries within itself the possibility of questioning of, and confrontation and conflict with the bourgeoisie of our "closed narratives"; and third, the theological understanding of interruption as an act of God that interrupts our closed narratives, acted out in our closed spaces. 


\section{MEDITATIVE INTERRUPTION}

\section{IN MEMORY OF ADRIAAN ENGELBRECHT \\ 04/02/1991-26/07/2019 \\ (1 Corinthians 13:12)}

\section{Background}

Adriaan Engelbrecht was born on the 4th of February, one day before our twins, Jacques and Karen. They were baptised a few months later, on the same day, in the same church. Adriaan was a truly gifted young man who struggled from an early age with the meaning of life. On the 26th of June 2019, at the age of 28, he took his own life. Adriaan was my son's best friend, the only child of Koos and Cecile Engelbrecht, who asked me to conduct the funeral service. The sermon underneath was initially preached in Afrikaans and is published here with the permission of Adriaan's family, in the form of a verbatim, English translation:

\section{Corinthians 13:12}

Dear friends and family, dear Koos and Cecile.

When we received the sad news about Adriaan on Friday evening, many memories and thoughts passed through my mind. I immediately thought back to that baptismal Sunday in 1991, a little more than 28 years ago - it was in the Student's Church of those days, where we held our services - when four children were baptised. One was the grandchild of Bun Booyens, two were my and Elna's twins, Karen and Jacques, and the other one was Adriaan. I realised again how far back our shared history with the Engelbrecht's went, and particularly the friendship between Jacques, my son, and Adriaan. Even though they were in different schools, they always kept contact. No wonder that Jacques could say that Adriaan was, of all his friends, the one that he knew the longest and best.

But on that sad Friday evening, a text from the Bible also came and stood broadly in my way - the text that we have read this afternoon from 1 Corinthians 13 , particularly verse 12 . It is a text that we do not traditionally hear at funerals, rather at weddings and other celebratory events - but then again, Adriaan was also not a traditional child and human being. This text, I must confess on a personal level, touched me deeply, comforting me. It sounds like this: 
For now we see only a reflection as in a mirror; then we shall see face to face. Now I know in part; but then I shall know fully, even as I am fully known. ${ }^{18}$

Here we hear of three ways of knowing, three forms of understanding. The first that we must understand is that we do not understand - we only know in part. Paul probably has the mirrors of those days in mind - not as clear as those that we have today, but rather polished, metal objects. All that you could see of yourself were vague outlines, skewed and distorted, indeed a dim image in a murky mirror. So it is with us - we look, but we see, and know, and understand only partially.

To say this with a more recent metaphor: we are like people sitting around a table on which the pieces of a puzzle lay strewn -5000 pieces. Perhaps we have fitted in a few pieces, here and there, perhaps somewhere on the borders of the puzzle, but the rest of it is still mixed up, chaotic, confusing. We do not see, do not understand the bigger picture - such are our lives.

Our lives consist of fragments. We are not like a marble statue, created by Michelangelo - not strong, polished, and steadfast on our foundations. Our lives are rather like pieces of rubble, lying around. Perhaps we can pick up a fragment here and there that makes sense to us, that could be fitted in somewhere, but the rest of it is out of our control. We know in part, understand in part, indeed.

There was a time in the history of the church when we thought that faith means to be strong, always, unshakeable, absolutely certain. But faith is not like that. Faith is rather to understand that you do not understand, to know that you do not know, yes, to have doubts from time to time. Martin Luther once said that faith is nothing else than comforted doubt. This is how our lives are: sometimes doubt, then again comfort; sometimes comfort, then again doubt. Sometimes we know something, and other times we ask: Why? Why, Lord?

When I heard the news about Adriaan, I also thought about a poem that someone once wrote, after the sudden death of his daughter - she was struck by lightning. It indeed came as a bolt out of the blue. The title of the poem is: $O$, the painful thought $\left(O\right.$, die pyngedagte), and the poet was Totius. ${ }^{19}$ Some verses from the poem sound like this:

O, the painful thought: my child is dead!

It burns like an arrow in me.

The people see nothing of $i$,

and the Lord alone knows what I suffer.

19 Totius was a famous South African, Afrikaans-speaking poet. He wrote volumes of poems, but, being a religious person, also contributed many psalms and hymns to the official Dutch Reformed hymnal. Some of his works can still be found in Die Liedboek, the current hymnal of the Dutch Reformed Church. 
The days come and the nights go;

the shadow's become long and again short;

the driver's voice of my work resounds,

and I continue on my crossroad.

But a pain continues to shoot through my heart, in such a way that my life's lustre is gone:

Your child has died a terrible death!

And - I clutch my breast in pain.

$O$, the painful thought: my child is dead!

It burns like an arrow in me.

The people see nothing of it,

and the Lord alone knows what I suffer.

Have you noticed how we name people who [have] lost loved ones? We classify them - a widow is someone whose husband has died; a widower, a man whose wife has passed away; orphans are children who lost their parents. But there is no name, no category for someone whose child or children have died. Could we call them 'orphaned parents'? Actually, this grief cannot be named, cannot be articulated. There are not enough words or names to describe it.

Truly, we only know in part.

But, now there is also a 'but' in our text, as is the case in many biblical texts. But ... then I shall know fully. With these words, everything I have said so far, in a sense, is turned upside down. One day we will no longer see a dim image in a murky mirror, but, as Paul says, face to face. One day we will not only see the face of God more clearly but will be face to face with them that passed away before us. One day, all our unsolved riddles, all our "why?" questions will be clarified, face to face.

One day we will, by way of speaking, sit around the table of eternity, and the pieces of the puzzle will fall into place right before our eyes. One day we will no longer be fragments, but completed and perfected. One day doubt and faith will no longer be replaced by each other, in a seemingly never-ending, tiring cycle, but doubt will be gone, and only comfort will remain. One day there will be no more poems about death, but only life and peace. One day there will be no more widows or widowers or orphans or orphaned parents, but only children of God in the family of God, living in the house of the Father, which has many rooms, many spaces filled with grace. Someday, grace upon grace will be fulfilled.

But we could ask - is 'one day' all that we have? Should we simply just persevere until 'one day'? No, for there is also a third part to our verse, and it was this part, particularly, that I pondered for a long time, and which comforted me deeply. 
Not only do we not understand, fully; not only will we understand, fully - but God understands us, now, fully.

People cannot understand one another fully, ever. We do not even understand ourselves fully. You could be married to someone for 60 years, and not understand that person, fully. We cannot even understand our parents or children, fully. Who could, for instance, understand what Adriaan went through, and what went through his mind the last couple of years and especially the last days and minutes of his life? Who could?

God could, and God did. Fully. God understands all of us this afternoon, and God understood and understands Adriaan, fully. The other word for that is love - the profound theme of 1 Corinthians 13. The fact that God understands us means that God accepts us, with love, through grace, without judgement and critique, without conditions or blame or shame. God receives us as we are, with love.

Could we say that Adriaan was received by God in this way during those last moments of his life - embraced by this unconditional, fully understanding love? I believe we can.

The Lord alone knows what I suffer.

And how would the Lord know this? Well, the Father also had a Son who died at a young age, in the prime of his life. This Son is called the Only Begotten Son of God. This Son also had his moments of doubt - My God, my God, why have you forsaken me?

But this Son was received into the eternal love of God, where He prepares a place for us, and where He prepared a place for Adriaan - in the house of the Father, with its many rooms.

This Lord alone knows what I suffer.

Dear Koos and Cecile, dear family and friends - this is our only comfort in our doubt and sorrow, today. 


\section{Chapter 1}

\section{GRACE: \\ TO KNOW THAT YOU DO NOT KNOW, FULLY}

There is nothing wrong with not knowing. On the contrary, it could be the most liberating knowing known to humanity.

Of course, we do know many things. Our knowledge doubles itself, triples itself at a breath-taking pace. We are quite knowledgeable. The future will, undoubtedly, bring with it insights as never before. We still stand starry-eyed in and before this universe, blinking in the disbelief of never-ending discoveries. The capacity for awe will not, should not, leave us - hopefully - because there is so much about to be in awe of, and always will be.

Take, for instance, two seemingly complete opposites, but stunningly similar entities: the cosmos and our brains. We now know that the cosmos came into being a long, long time ago (13800000000 years, give or take a few million), but we do not know what came before the cosmos - if 'before' is at all the appropriate word to use here, being a temporal notion. This cosmos is so vast, so expansive, that our brains boggle when observing it.

Speaking about boggling brains: our brains is something about to boggle our brains. Of course, you could measure its dimensions within our skulls, but we seem to fail to fathom the mysteries of the wiring within it. Inside this compact apartment, you find ever-changing and stunningly adaptive electric-magnetic impulses, flashes of synapses, coding of information, storage of memories, emotions of empathy, human consciousness (perhaps the biggest mystery of all) - you find throbbing 'life.' Who understands this?

On the one hand: a macro-cosmic explosion of matter and movement, of stars and space, of planets and power, of galaxies and gravity; on the other: a brain, pulsating with micro-cosmic networking's of humanity, of 'life'. Who understands this?

These stunning brains seem to be ever inquisitive, somehow connected to this everexpanding cosmos. Some mysterious synapse seems to spark between them. As human beings, we always long for 'more', or 'deeper', or 'higher'. Somehow, within us, there lurks the longing, the thirst, for what is often called 'the meaning of life', making us human, amongst other things. 
People have tried, in many ways, to quench this thirst, to still this longing. In the end, however, it keeps on coming back. We try our best, most of the times, to run away from it, but we cannot. Like our shadows, we cannot shake it off. Sometimes, it even outruns us, often darkening the way ahead of us. It need not; it should help to light the way.

The most fundamental questions that any human being can pose are: Why? Whereto? How? ${ }^{20}$ Or, to phrase it differently: what are the reasons for our existence? Why is there something, even someone - like me, for instance - and not nothing? Not no-thing? If there is something and someone, and not nothing, whereto is all this headed? Somewhere? Nowhere? Into the abyss of no-thing?

Furthermore, if there is a reason for something and someone to be here, and to be headed somewhere, how should this process, this existence, be lived out? In other words, what makes this life meaningful? We are coming from somewhere, and we are headed somewhere, so how to be, to exist, in-between?

Let us ponder this first question for a while: Why? What are the reasons for our existence? Or, as in the first part of Gauguin's artwork title, referred to above: Where do we come from? I remember sitting under the Karoo night sky one evening, some years ago, and realising, once again, that this cosmos is our home. ${ }^{21}$ We do come from the cosmos; we are part of the cosmos, and we do return to the cosmos. It might seem like a place of chaos, with space and power and movement interacting in a seemingly chaotic manner. There is a beautiful order to this cosmic chaos. My own, aesthetic response to this 'cosmic homecoming' was to try and depict it, as follows:

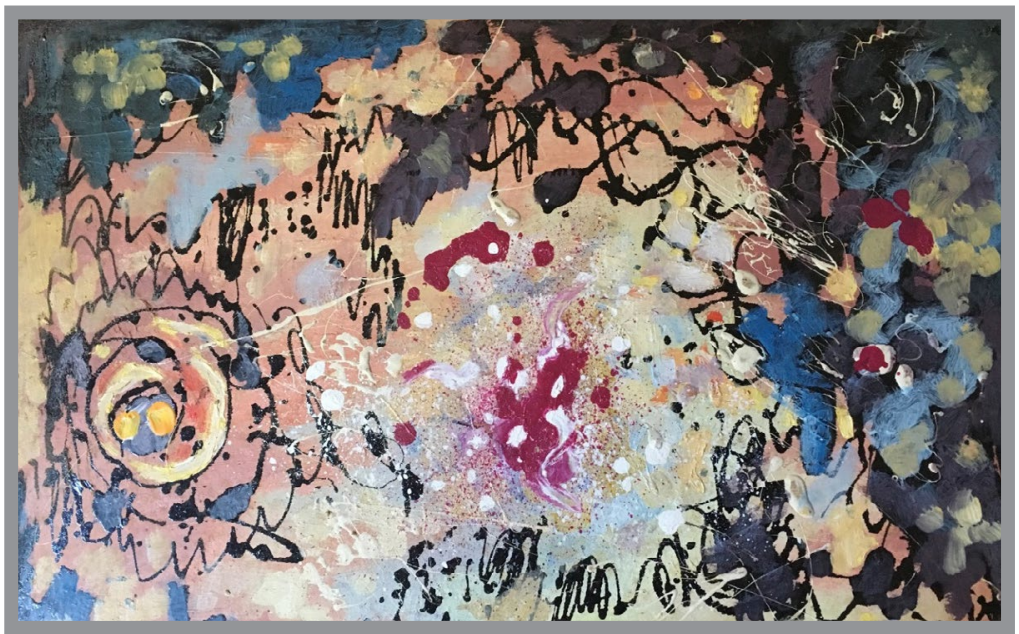

FIGURE 2: The beautiful order of cosmic chaos (1995) by Johan Cilliers.

20 See Hennie Rossouw, 1984, Die Sin van die Lewe, $27 \mathrm{ff}$.

21 The Karoo, a dry and arid landscape in South Africa, forms an important metaphor for my theological thinking. See the discussions and references further on. 
We try and decipher the cosmos' meaning with our minds, try to find the reasons for its and our very being. In doing this, we could either end up being despondent and even nihilistic, or responsive and amazed. To a certain extent, the choice is ours.

Let us go on two journeys - it might help us in this regard.

First, we travel 'outwards' into space and from about 10000 kilometres away you see the round shape of our blue planet, with some continents still visible. Another 100000 thousand kilometres away and earth becomes a small ball against a pitchblack cosmic backdrop. Ten million kilometres from the earth you travel through the asteroid belt. Then another 100 million kilometres past the inner planets. Ten billion kilometres further brings on the Kuiper Belt and with another 100 billion kilometres you pass the dwarf planets (by now we should start travelling at the speed of light, i.e. in light-years). You are set on your way to a viewpoint from one million light-years away, with spectacular images of our milky way, as well as our galactical neighbourhood. Ten million light-years further on and ... well, so it goes. You get the picture; you are 'far' out, and yet this is still only a small step into the cosmos. If you keep on travelling (at the speed of light, of course), you will end up at the end (?) of the so-called cosmic web, about 10 billion light-years away from earth.

Let us now come back to this earth, and travel 'inwards', into our cranium cavity. After about 10 millimetres, we might find a blood vessel; another 100 micrometres brings us to a white blood cell; 100 nanometres further, we come upon a DNA strand; at 10 nanometres, we might see a chromosome tip; then we travel 100 picometres, towards an oxygen cell; another 10 picometres bring on the inner atoms; 1 picometre and you enter atomic emptiness; 10 femtometres and you are surrounded by neutrons and electrons; 1 femtometre deeper and you are delighted by some quarks ... well, I think we are deep enough now, into the mystery.

Cosmos and brains, brains and cosmos - full of darkness, light, coldness, warmth, death, life, movement, hope - and, somewhere between ten billion light-years and one femtometre, am I - being part of it, partaking in it. Perhaps a speck on a seemingly insignificant spiral somewhere in the vastness of space; a brief brushstroke on a breath-taking blob of cosmic beauty; a neurological spark in a splattering of pulsating powers ... but I am there.

I am here now.

This picture - of the vastness of cosmic space and the mysteries inside our cranium's space - puts everything in perspective, puts us in our place. 
I have a cure for megalomania. It is called: Karoo. ${ }^{22}$ As life happens, all my confessions and convictions and exclamation marks, as articulated above, are turned upside down from time to time. It then becomes a cry, a doubt, a painful question:

Why am I here, now?

Sometimes, when catastrophes strike, and life seems completely 'out of order', even this cry of doubt might not do justice to the feelings of despondency, darkening your existence. When the outlook on (your) life becomes so bleak, so seemingly hopeless, that nothing 'makes sense' anymore - then the painful question 'why?' could even take on the form of a statement, a sigh, born from the 'dark night of the soul. Then it says:

I do not want to be here, now, anymore.

This would be the deepest pit of darkness - the feeling that grace has been replaced by gracelessness; that it has been cancelled, deleted - that, instead of grace upon grace, grief upon grief now reigns.

Whenever this happens, I would sit outside in the Karoo once again, under the stars. On a clear night sitting outside in the Karoo, you can see, in a way even touch, the 'beautiful order of cosmic chaos', that is 'the beautiful chaos of being. ${ }^{23}$ Then you know: chaos (i.e. not-knowing the order) is good. It harbours within itself the possibility of order, resurrection, of life.

I must confess, this makes me feel much better about my life. It reminds me, once again, that we should not take ourselves all that seriously. ${ }^{24}$ So, let me shift, for the moment, from the sublime to the (seemingly) ridiculous. This knowledge that chaos is good makes me feel better about the state (of disorder) of my so-called office. One of my (very creative) $\mathrm{PhD}$ students once drew a picture of my office, from memory. His take on the 'beautiful order of cosmic chaos', which constituted my office looks like this:

22 The name Karoo originates from the Khoi word Karus, meaning dry, barren, thirsty land. It is a semidesert natural region in South Africa. Its inland section, the Nama Karoo, has two main sub-regions the Great Karoo in the north and the Little Karoo in the south. The Great Karoo is a vast and desolate region north of the Swartberg range; the Little Karoo is a fertile valley boundered on the north by the Swartberg and on the south by the Langeberg and Outeniqua mountains. The western section is the Succulent Karoo, situated in a winter rainfall region near the Atlantic coast. Cf. Chris Schoeman, The Historical Karoo: Traces of the Past in South Africa's Arid Interior, 8-9. Many indigenous names describe the nature of the Karoo, for instance: Moordenaars-Karoo (Murderous Karoo), Hardemans-Karoo (Hard man's Karoo), etc. See my discussion in Johan Cilliers, A Space for Grace: Towards an Aesthetics of Preaching, $1 \mathrm{ff}$.

23 Nietzsche spoke about the 'beautiful chaos of being' (schöne Chaos des Daseins). Friedrich Nietzsche, 1973, Die fröhliche Wissenschaft, 201.

24 See further discussion in Chapter 1 and in the Conclusion about the role of playfulness in the search for meaning. 


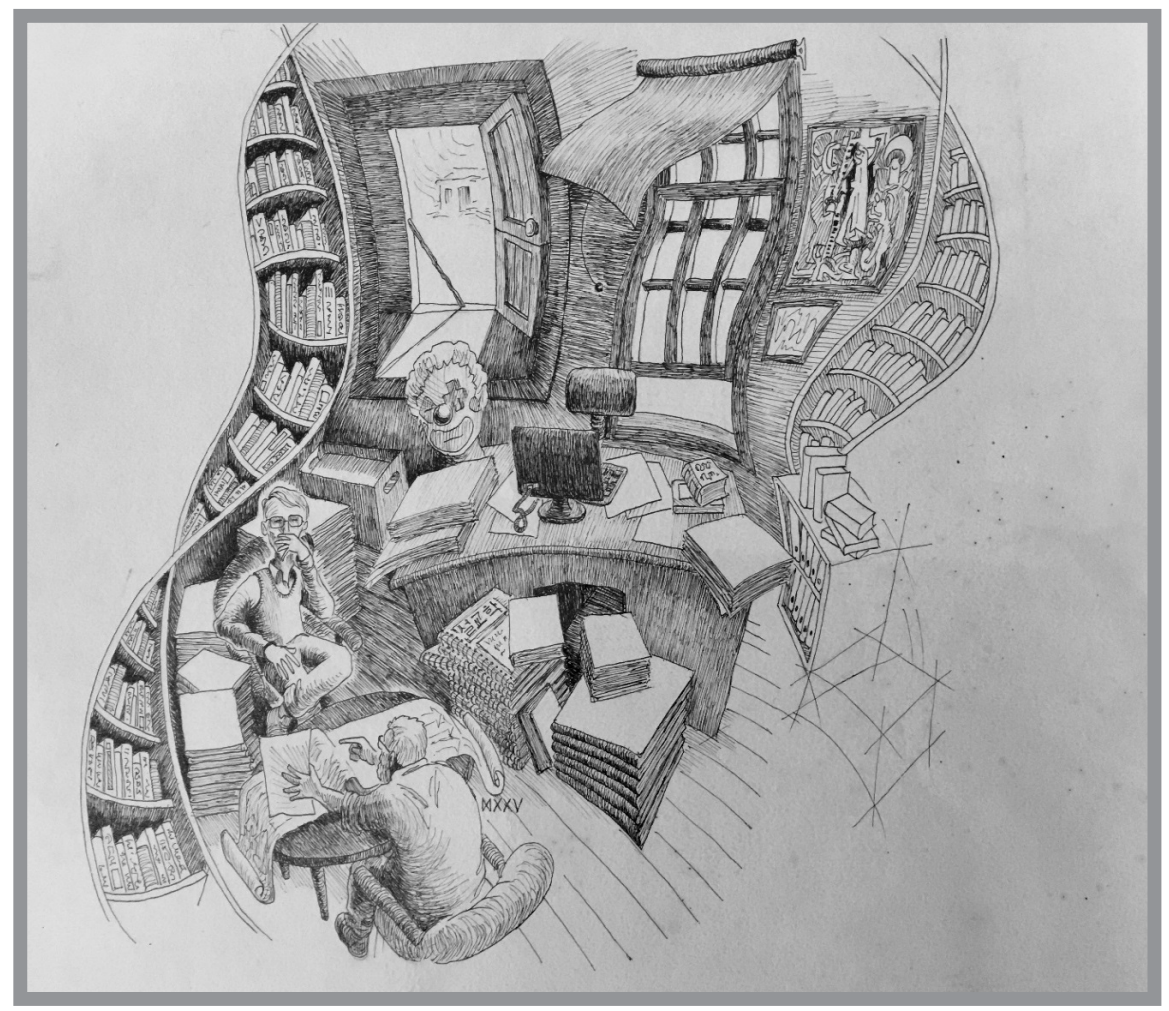

FIGURE 3: Official Chaos (2019) by Martin Mostert.

What struck me was the detail - amongst the swirling movements of chaos. Particularly the painting of the open door (top, left) with the walking stick, the latter waiting to be picked up in response to the calling of the open road - a road inviting us to walk along this way, leading towards the 'beyond', which could be called 'home' ... ${ }^{25}$

To the right, at the top, the imprint of Picasso's Crucifixion hangs on the wall, a painting that has fascinated me for a long time, and still does. Underneath the painting with the walking stick, the clownish face that has been part of the set-up of my office I think forever, also makes its appearance. ${ }^{26}$ For me truly astounding, my student remembered the almost always open window, with the curtains fluttering in the wind. Perhaps he interpreted it as a symbol of movement, of change, of liminality?

I think he sensed: in this space, chaos is good, and fragments are in (or is it out of?) order. Here, 'order' would be extraordinarily out of place.

25 See the cover page; see also the discussion of this painting in Chapter 2. 
Oh, and just in case you wondered: the one who covers his mouth with his hand, sitting in a pondering position - that is me.

During the late 1980s, the German practical theologian Henning Luther introduced the notion of 'fragment' with its origins in aesthetics, into the theological debate. ${ }^{27}$ He turned to the concept of the fragment to challenge a specific understanding of 'identity' that professes to deliver and maintain a product that is completely intact and fully integrated. ${ }^{28}$ Luther opted to speak about identity as not-being-whole, not-being-complete, and constantly-being-interrupted, that is, the 'fragment.' ${ }^{29}$ This understanding of identity as fragmented stands in stark contrast to one of totality, of a state of closed-in-itself wholeness, of unfailing unity, and continuous and unchallenged relevance. ${ }^{30}$

According to Luther, there are fragments from the past as well as fragments from the future. ${ }^{31}$ The 'fragments from the past' are those pieces of unfinished business that were never resolved, those shards of a once-intact but the now-destroyed whole, haunting us as torsos, as ruins, reminding us, amongst other things, of our guilt. These fragments from the past can create experiences of pain and anguish, leading to mourning and lament. In this regard, Luther even speaks of an "aesthetics of confession".32

The 'fragments of the future', on the other hand, signify unfinished business that has to do with those experiences and endeavours of life that have not yet found their ultimate form and completion. These fragments of the future evoke feelings of longing - feelings that prevent us from dull acceptance, or worse, hardening or solidifying. ${ }^{33}$ These longings help us to remain open and fluid towards the future. ${ }^{34}$

Past and future fragments point to possibilities, something other than and outside of themselves, that need to be fulfilled. ${ }^{35}$ The unique contribution of Henning Luther lies in the fact that he interpreted the aesthetic notion of fragment in an innovative, theological way. Luther is convinced that the notion of fragment runs like a golden thread throughout all the classic theological topoi. It, for instance, gives profile to the

This discussion is taken as an excerpt from Charles Campbell and Johan Cilliers, 2012, Preaching Fools: The Gospel as a Rhetoric of Folly, 45-48.

Ibid., 161.

Ibid., 180-182.

Ibid., 167.

Ibid., 182. A striking example of this fragment from the past can be seen in the Church of Remembrance (Gedächtniskirche) in Berlin: a church bombed during the Second World War that was not renovated, but left as a ruin to act as a monument of remembrance for the generations to come. Next to it a modern church has been built - intended as a contrast, adding to the architectural tension of fragment and completion', placed within a few metres of one another.

33 Ibid., 169, 170.

34 Ibid.

35 Ibid., 167. 
key concept of 'faith', preventing identity from becoming an immovable monument, instead of fostering a specific understanding of faith: faith means not to be intact, but to live as a fragment. ${ }^{36}$

Fragmentation also fosters a specific understanding of 'love'. Love involves grasping that we are not the only fragment on this earth and that our conceptions of identity are continuously challenged by others; that we are bound to one another and should create space for each other, in love. ${ }^{37}$ Love is not a nebulous concept - it calls for self-sacrifice and service, for the sake of others. We could add that it is through selfsacrifice and service, for the sake of others, that meaning in life is found, and created. The meaning of life is indeed to give meaning to life - the lives of others.

Those who understand something of their brokenness cannot be without love for others who are also broken. They know from existential experience that fragments can and should coexist in love; they must not be allowed to develop rigid boundaries or exclusive clubs. 'Sin' can be understood as a form of identity that seeks security in set and final statuses, directly the opposite of being a fragment. ${ }^{38}$

Of particular importance for this book: Luther argues that the notion of fragment is best underlined by the keyword 'grace', which implies an understanding that we are not yet whole, but continuously being made whole by Another. ${ }^{39}$ We are indeed fragments, but not loose-lying bits and pieces; we are continuously being fitted into a larger picture of fulfilment - being part of the cosmic puzzle. This continuous being 'fitted into' could be called 'grace upon grace'.

For Luther, the cross of Christ represents fragmentation par excellence. Jesus was not, in this sense, an ideal and 'whole' human being. He was broken, pierced, crucified, and fragmented. This fragmentation is furthermore not annulled by the resurrection; the resurrection is not the negation of the cross, but its validation..$^{40}$ The resurrection says, "This broken and fragmented Christ is none other than God." The resurrection deepens and radicalises the reality of the cross. It also gives hope that the fragments of our existence are being bound together in a new whole. ${ }^{41}$

It is important to understand that there is no logical connection between crucifixion and resurrection. The leap from crucifixion to resurrection is strange, surprising, and

\footnotetext{
36 Ibid.

37 Ibid., 170.

38 Ibid., 172.

39 Ibid., 173.

40 Ibid., 173.

41 Manfred Josuttis would add to this insight by saying: “... when the Spirit of Christ lives in us and we become part of the history of Christ, our fragmented identity participates in the consummation of the resurrected Christ." Josuttis in fact speaks about 'conversion' rather than 'identity', because 'conversion' intends transformation, while 'identity' has conservation in mind - therefore, rather conversion than conservation. Manfred Josuttis, 1998, Identität und Konversion, 117-118, 126.
} 
puzzling, not something dictated by logic. It is not something we would 'normally' perceive, or simply hear and take to heart. ${ }^{42}$ In this regard, the Spirit must give us discernment.

From the perspective of 'hope', the fragments are real, but not meant to be eternal incompleteness; they are indicators and forerunners of the consummation of fullness. ${ }^{43}$ This understanding of the fragmentation of life gives hope, but can also create feelings of unrest, of knowing that we have not yet arrived at our destinations. In fragments, lament and longing are bound together; in fragments, fullness as notbeing-there is present as being-there. Fragmentation thus characterises Christian life in the liminal space between the ages. ${ }^{44}$

Luther's theological understanding of identity and fragment represents brokenness, but as such call for, long for, wholeness - and so create hope. ${ }^{45}$

I reiterate there is nothing wrong with not knowing. There is something like thealthy uncertainty', as sure as there is something like 'unhealthy uncertainty'. There is also something like 'unhealthy certainty'. There are few places where we find so many examples of this unhealthy certainty than on pulpits, sadly enough. Often, preachers 'know' too much - about people, but particularly also about God. Often, they act and speak as if they know people, fully, and have attained knowledge, fully - also about God. Often, they are so sure who God is, so certain where and how God acts, and even where and how God should act - according to them.

Take, for instance, the following prayer from a worship service, in which the preacher articulates his absolute certainty about people's thoughts and God's works: ${ }^{46}$

But, while I administer the Word, there were people who said that I yearn for it. Thank You Lord, that, through the Holy Spirit, You have already brought about change, that the people already have renewed their thoughts. But, thank You very much that You now have changed their attitudes in a supernatural way and that they realise that God has

42 Luther, Religion und Alltag, 127.

43 Ibid., 175 . See also the discussion later.

44 Ibid.

45 This seems to resonate with Martin Luther's understanding of a theologia crucis. In his Heidelberg disputations (section 21), Luther states that, while a theology of glory speaks well of the bad and calls the bad good, it is the theology of the cross that describes essential reality and perceives being in terms of its essential characteristics (matter as it is). Martin Luther, 1883, 1518, Disputatio Heidelbergae habita, 354: "Theologus gloriae dicit malum bonum et bonum malum, Theologus crucis dicit id quod res est." In section 20, Luther states that the visible, as well as the not-yet-revealed (or future) aspects of the presence of God should be perceived from the perspective of suffering (the cross). In this sense, the cross becomes a resource of comprehension and understanding - and therefore hope amid suffering. Martin Luther, 1518:354: "Sed qui visibilia et posteriora Dei per passiones et crucem conspect intelligit." For Luther, the most authentic locus of our human knowledge of God is the cross of Christ in which God is revealed and yet, paradoxically, also hidden away. God is revealed in the passiones et crucem - yet, God is simultaneously hidden in this revelation. 
made them new ... Thank You Lord that You have also served those who are in a crisis in this morning. Thank You that You have helped those who are in need this morning, although their circumstances are still the same, their predisposition is different, because You have renewed their thoughts.

One could accept that these are all things that the preacher would have liked to see happen, so much so that he even uses a type of prophetic past tense to describe it. However, it is a question whether all is so in reality, or has happened anywhere near to how the preacher has expressed it, or whether it represents some form of religious manipulation. Take note: all these 'supernatural' things took place “... while I (the minister, JC) administer the Word”.

One hears a similar tendency in another sermon:

We are at the end of an outreach week where we reached so many hearts, have touched so many people, brought so many into touch again with a new life that we find in Jesus Christ, through music, singing, and a radio transmission.

How does the preacher know all of this? Does he have insights into God's mind that others do not have? Into the mystery of peoples 'hearts'? Is this not a form of pious arrogance? Or, perhaps on a subconscious level, the preacher is trying to project (supernatural) legitimacy onto his ministry? Take note, again: the heuristic principle of all these supposed events lies in the word 'we': "... we reached so many hearts..."

The Lord's desires, sayings and works are often presented as identical to what the preacher wants, says and does, for instance in phrases like the following:

[...] via the Word, the Lord says to you this morning [...] This morning I say to you [...] that is why you must now listen to me [...] I told you that God wants [...].

The preacher places his sermon in God's mouth. Would it be too harsh to call this a type of homiletical megalomania? The Lord says ... I say ... I say ... the Lord says?

The great number of 'I's that teem in so many sermons are indeed significant. Sometimes, the sermon exists literally of only a dialogue between the 'I' of the preacher and the (distant) congregation, without it ever becoming a dialogue between God and God's congregation. Much can be inferred from how preachers use the words, 'we', 'I, 'you', 'they', and especially the connections that they presume or lay between these concepts. It would not be an exaggeration to say that preachers often, in their person, and with their insights, experiences, faith, become 'the' point of revelation of the sermon, where all lines are joined and unravelled in a "hermeneutics of the I" ${ }^{47}$

47 See my discussion of hermeneutics in the Conclusion. 
A good (bad!) example of this is a sermon in which the second paragraph is introduced as follows:

Should I ask you a question this evening, and I would say 'what is an outstanding characteristic of a Spirit-filled child of the Lord?' then I believe we will hear many answers this evening.

The preacher follows this paragraph with a long list of answers he provides on behalf of the congregation, ultimately swept off the table by the 'I' in the sermon:

I think that these answers, which you give, cannot save you ... But, I tell you now, Jesus Christ gives us the clearest answer and the correct answer...

The preacher is the one who asks the questions, provides the congregation's answers to these questions, declares them as wrong (i.e. not 'correct'), and then comes to the fore with the patented, Christological solution - "the clearest and the correct answer".

The preacher's 'I' brings about and completes the so-called 'hermeneutical circle'. Everything circles around this 'I', evident throughout the rest of the sermon quoted above, where we hear ad nauseum:

And I want [...] I want to tell you [...] I want to tell you you live in abominable sin. You say: 'How do you manage it?' I succeed because the Word of the Lord says to us 'Be filled with the Holy Spirit' [sic] [...] I know there's an entire transformation that must take place in your life, etcetera [...].

This preacher knows all, wants, says, and does all that is necessary to make his sermon 'work'. That which 'works', is not necessarily 'true.' In reality, or at least grammatically speaking, no space is left in these hermeneutics of the 'I', for the work of grace. The Gospel is put out of action. 'I' replaces it.

I would call this situation: 'unhealthy certainty'. Sometimes, we even know too much about the devil. As in the following:

The devil has certainly come to every service that I've ever preached. The sound goes wrong, people fall down, they sneeze and cough and do all kinds of things because the devil disturbs people.

How the devil does the preacher know that the devil 'certainly' attends every sermon that he preaches? Is this not how he/she brings listeners under the impression of authority with which he/she (always) speaks, and that in 'every' service? A person who can move the devil in such a way must 'certainly' have impressive authority, not so?

In some instances, this syndrome of unhealthy certainty takes on even more extreme forms. During the Black Death plague, for instance, which killed about $60 \%$ of the 
European population in the Middle Ages, many were quick to blame it on the sin and guilt of many 'others' (not themselves, of course). The disaster, caused by a bacterium (Yersinia pestis), was used as a handy tool, not only to blame others, but to 'activate' God's wrath - a primitive tool indeed, that had no knowledge of, or eye for, God's compassion for human beings.

Nevertheless, not all shared these sentiments. The tone of Martin Luther, for instance, is different and indicative of a theological maturity way ahead of his times:

I shall ask God mercifully to protect us. Then I shall fumigate, help purify the air, administer medicine and take it. I shall avoid places and persons where my presence is not needed in order not to become contaminated and thus perchance inflict and pollute others and so cause their death as a result of my negligence. If God should wish to take me, he will surely find me and I have done what he has expected of me and so I am not responsible for either my own death or the death of others. If my neighbor needs me however, I shall not avoid place or person but will go freely as stated above. See this is such a God-fearing faith because it is neither brash nor foolhardy and does not tempt God. ${ }^{48}$

As I write these words, the globe is in the grip of the coronavirus (COVID-19) pandemic, reaching its apex in many countries, and resulting in millions of people being infected, and thousands dying. ${ }^{49}$ Currently, as I write these words, in South Africa we are in a 'national state of disaster', undergoing an (initially 21-day) lockdown, during which people are not allowed to leave their houses, except for essential things like buying food and medical supplies or going to a doctor or hospital, with a real possibility that it might be extended. This worldwide disease has brought out the best, but also the worst in people.

For instance:

» A retired British military officer, Captain Tom Moore, celebrated his 100th birthday by walking up and down in front of his house with his walking-ring a hundred times, in aid of a relief fund for COVID-19 victims, and received over 30 million British Pounds in donations.

" Some ANC counsellors, who were supposed to distribute food parcels to poor people in dire need in South Africa, channelled parts of it to (wealthy) friends and family.

And so on.

Speaking of the worst: it was difficult to believe, but during a recent early morning radio broadcast a so-called theologian bluntly declared that the reason for the

48 Martin Luther, 2016, Pastoral Writings, 43.

49 I started to write this book on 13 February 2020. The first COVID-19 viral infection was reported in China in December 2019. The first incident of infection in South Africa was reported on 5 March 2020. 
pandemic brought about by the coronavirus must be squarely placed on the shoulders of the Chinese people - not only because the pandemic allegedly started there, but because they are non-Christians, of course. The deaths of thousands of people are all the results of people's sin, and God's fitting wrath - so his argument went. It seems as if the tendency to draw dead-sure connections between God's judgement and people's behaviour, can be seen even today, and particularly amongst people who really should have known better. ${ }^{50}$

I remember one such certain sin-indication and wrath-proclamation from my younger years. A Karoo town in South Africa was hit by catastrophic flooding which itself was a shockingly unfamiliar event, given the semi-desert nature of the landscape. On 24 January 1981, the tiny, rural town of Laingsburg was overrun with masses of water after the sluices of heaven (?) were opened. At least a hundred residents drowned, and the bodies of another 72 never found. A total of 184 houses were destroyed, with only 21 left standing. In effect, the town was wiped out. Why?

Well, many answers were given. I remember one sermon, particularly, as if hearing it today. The preacher drew the lines, without hesitation that the town was struck by the judgement of God because the government of the day (take note: the apartheid government) allowed casinos to be built in the neighbouring so-called 'homelands' (which were, of course, a project of the very same apartheid government). I remember the preacher's absolute and crude certainty when uttering these statements, and, even sadder that so many took it as truth. Surely, this preacher knew exactly how God's mind worked, knew how and when God should act - in particular if these acts were aimed at the 'others'. This preacher knew, not partially, but fully.

Of course, there is also, as already mentioned, something like an 'unhealthy uncertainty'. This is not what I have in mind here. When Paul says: "For I am convinced...", he is not in two minds. ${ }^{51} \mathrm{He}$ is not wavering, not unsure of what he says. On the contrary, he articulates, and exemplifies what could be called a healthy certainty'. The latter, however, should never lead to homiletical megalomania or a theological know-it-all, or some other form of pious arrogance.

Sometimes we need to be reminded of this, as painful as it might be for our (homiletical and theological) egos. When I was about 46 years old, at the prime of my so-called 'preaching career', my daughter was ten years old, and, of course, had to sit through most of the worship services I preached. Well, she once drew her interpretation of these events. In retrospect, it is a remarkable depiction: 


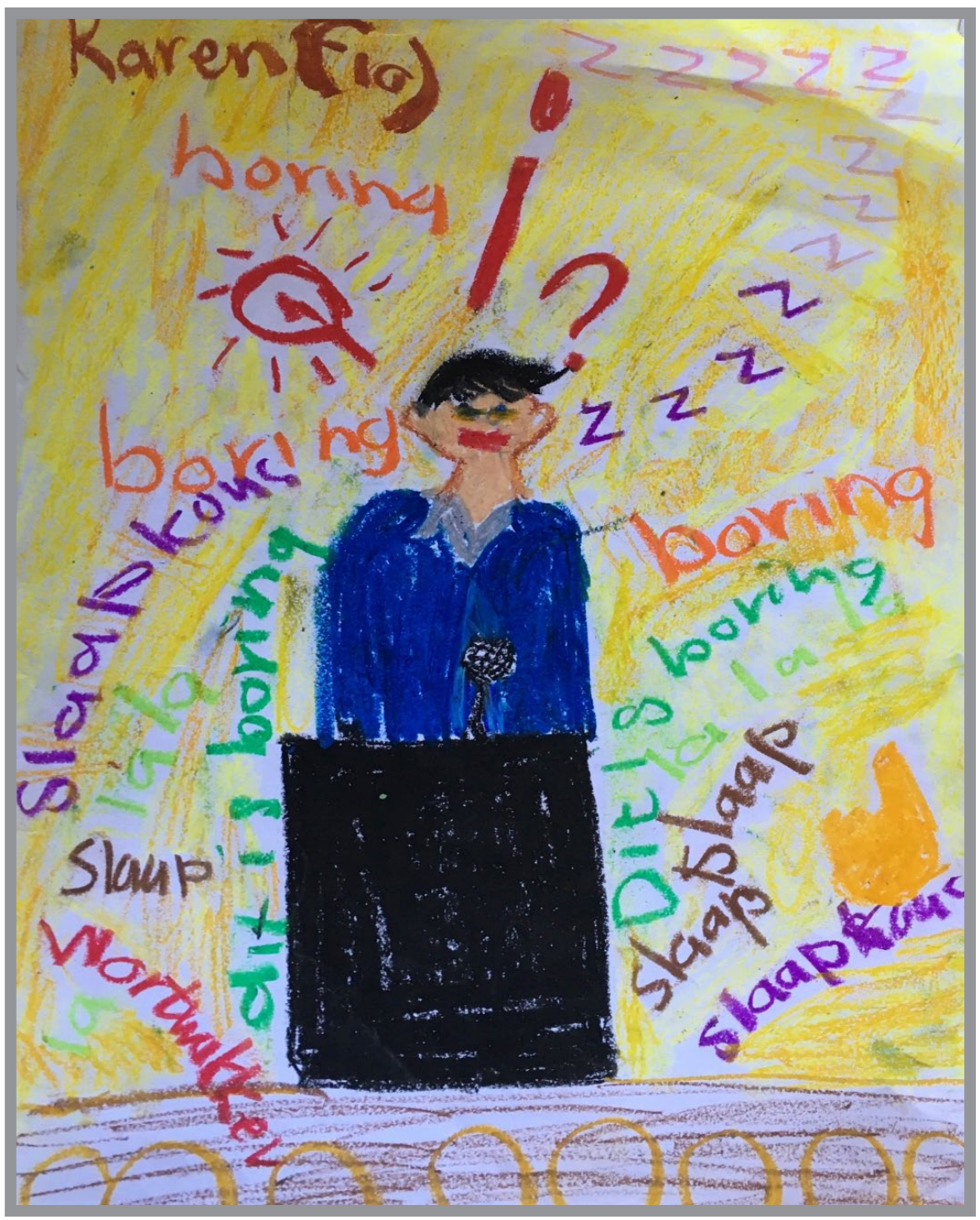

FIGURE 4: zzzzzzzzzz ... (2002) by Karen Cilliers.

Yes, the man behind the pulpit is me, her dad. There are (besides the invisible, inaudible sermonic words) some interesting phrases flying around:

» 'boring' (three times, in orange);

» 'it is boring' (twice, in green, partially in Afrikaans, our home language, 'dit is boring'); 
» 'sleep' (three times, in brown, in Afrikaans, 'slaap');

» 'sleepy head' (twice, in purple, in Afrikaans, 'slaapkous');

» 'wake up' (once, in red; interestingly enough, near or aimed at the heads of the congregants below, in Afrikaans, with the only spelling mistake in the depiction 'wortwakker' - instead of 'word wakker').

Most telling, the sounds 'lala' (twice, in light green; reminiscent of 'blabla', or a lullaby?), and the droning and dosing off $z z z z z z z z z z$.

Take note, the heads of the listeners (bottom of the picture) are transparent and empty. Take note: the pulpit is pitch black (symbolic of something?). Take note: most curious of all - the expression on the face of the preacher - bewildered, amazed, uncertain? All of these? Above his head float three signs. A light bulb, flashing indicative of at least some insight? A question mark - underlining the uncertainty of the man behind the pulpit? Most interesting, an exclamation mark, but turned upside down. Did the artist sense that the excitement and amazement of the preacher are, well, not as it could or should be, literally turned upside down? Or was she simply drawing this part of the picture with the latter being upside down? From an upside perspective?

Mystery: there is a light orange blob on the right - indicative of what? A hand and finger pointing upwards? A woollen cap for the sleepyhead? Even my daughter could not explain this, after 18 years. Obviously, she is quite clever and holds a $\mathrm{PhD}$ in neuroanatomy at the age of 28. Enough said.

We know, partially. Paul also adds: "... we preach God's will, partially."52 For now, this is how it is. I was reminded of the classic lyrics, written by Earl Wilson Jr in the late sixties. The title, How small we are, how little we know, says it all..$^{53}$ The words ring true, fifty years later:

We laugh, we cry,

We live, we die,

and when we're gone, the world goes on.

We love, we hate, we learn too late,

How small we are, how little we know.

521 Corinthians 13:9.

53 The song was published by Glamorous Music, Inc. and the sole selling agent is: Cimino Publications Incorporated, 436 Maple Avenue, Westbury, New York. Commercial recordings of the song discovered so far are: Robert Goulet, Both Sides Now, 1969 (Columbia 9763); Johnny Mann Singers, This Guy's in Love With You, 1967 (Liberty Records LST-7587); Josef Locke, How Small We Are How Little We Know, 7, United Kingdom, 1969 (Decca, 12925); The World of Josef Locke Today, CD, 2004 (Dutton Vocalion 8106). This song was featured as the closing theme to the film The Adding Machine (1969), starring Milo O'Shea and Phyllis Diller, based on the play by Elmer Rice. 
We hear, we touch, we talk too much, of things we have no knowledge of.

We see, we feel, yet can't conceal, How small we are, how little we know.

See how the time moves swiftly by, We don't know how, we don't know why.

We reach so high, and fall so low, The more we learn, the less we know.

Too soon the time to go will come, Too late the will to carry on, And so we leave too much undone, How small we are how little we know.

So it is. But Paul does not say that we know 'nothing. We know 'partially', which means that we do know 'something. We can fit some pieces of the puzzle, and we can collect and (re)arrange some fragments lying around. This could in fact be quite meaningful, giving new perspectives on the quest for the meaning of life.

This collection and re-arrangement of fragments call for a creative mode, a habitus of bricolage. This notion comes primarily from the world of aesthetics but also has been used in other fields, for instance, literature (where it denotes the hermeneutics of inter-textuality), critical theory, anthropology, philosophy, education, business, computer software, etcetera.

The term 'bricolage' comes from the French language, and originally meant something like 'do-it-yourself' (DIY), inclusive of notions like improvisation, making use of what is available. The French verb, bricoleur, actually means something like to 'tinker around', i.e. to play with possibilities, continuously asking: what if? In art, it would denote works created by making use of a diverse range of available materials, or mixed media.

To be a 'bricoleur', would entail observing keenly, being open for what is at hand, and re-constructing, re-mixing, and re-purposing these objects or ideas - with the often-surprising result of reproducing new meanings and perspectives. The point here is that the artist does not know what the outcome will be, at least not in defined detail. There is an openness, a stance of expectancy, an embracement of being led into the mystery. Here, particularly, not-knowing is good, even essential. Knowing (beforehand) could be detrimental, or at least, conducive to utter boredom and superfluous repetition.

Various art forms could be linked to 'bricolage'. Let us play around (tinker!) with only one exponent of such art: Marcel Duchamp. His (in)famous artwork titled, 
Fountain (1917), would probably be best known..$^{54}$ Duchamp was the first artist to introduce the concept of 'ready-made' or 'found objects' to the art world, and, in so doing, challenged the traditional preconceptions of what art is or should be in typical Dadaistic fashion. ${ }^{55}$

The idea of 'ready-mades' exemplifies the fact that nothing is 'real' in itself, and that everything could at best be described as adiapharon (something without value, until evaluated - admittedly within and therefore bound to the evaluator's psychological, cultural and social frameworks). This is what Dadaism, amongst other things, tried to achieve: to challenge the art world with its set beliefs about (the depiction of) reality. Dadaism protested against the snobbery and traditionalism of the art establishment and warned against a narcotic stupor within aesthetics. As such, it represented a type of 'anti-art', for the sake of art.

Duchamp decided not to use paint to create art anymore but selected 'ready-made' objects, often mass produced, commercialised, and utilitarian, and placed them in such new, and often strange contexts and perspectives, that they somehow called forth new meanings. He departed from the ancient notion that art could only be created by a highly skilled creator, delivering 'original' works of art. On the contrary, he believed that 'ordinary' objects harboured within themselves the "dignity of a work of art by the mere choice of an artist".56 Importantly, 'dignity' did not equate 'beautiful' in Duchamp's mind, at least not the traditional, romanticised idea of 'beauty. ${ }^{57}$

The first 'ready-made' art that Duchamp created was titled Bicycle Wheel. In his own words: "I had the happy idea to fasten a bicycle wheel to a kitchen stool and watch it turn." ${ }^{58}$ The depiction below is the third version of Bicycle Wheel. The first, now lost, was made nearly 40 years earlier, in 1913.

54 The work simply consists of a porcelain urinal taken out of its customary setting and placed in a new and unfamiliar one, namely an art gallery. Duchamp submitted, Fountain, under the pseudonym "R. Mutt" as a type of prank, but also as a critique on some of the most basic conventions of (avant-garde) art. The organisers of the exhibition were furious: Was the artist equating modern art with a toilet? Fountain was promptly removed from the exhibition, and mysteriously 'disappeared' thereafter. It was simply too scandalous for the art establishment of the time. See my discussion in Cilliers, Dancing with Deity, 216ff. Kristina Seekamp, 2005. Unmaking the Museum: Marcel Duchamp's Readymades in Context: Bicycle Wheel.

56 Ibid.

57 Many view 'beauty' through a haze of romanticism. For them, beauty is all about objects (or experiences) that are, fine, excellent, noble, and honourable. Beauty is seen as "the pretty, the merely decorative, or the inoffensively pleasant", its intention being nothing more than merely evoking a sentimental feeling about pretty sunsets and artistic flower arrangements. Cf. David Hart, The Beauty of the Infinite. The Aesthetics of Christian Truth, 15. See also Johan Cilliers, Fides Quaerens Pulchrum: Practical Theological Perspectives on the Desire for Beauty, 257-268.

MoMA Learning. 2020. Bicycle Wheel: Marcel Duchamp. 


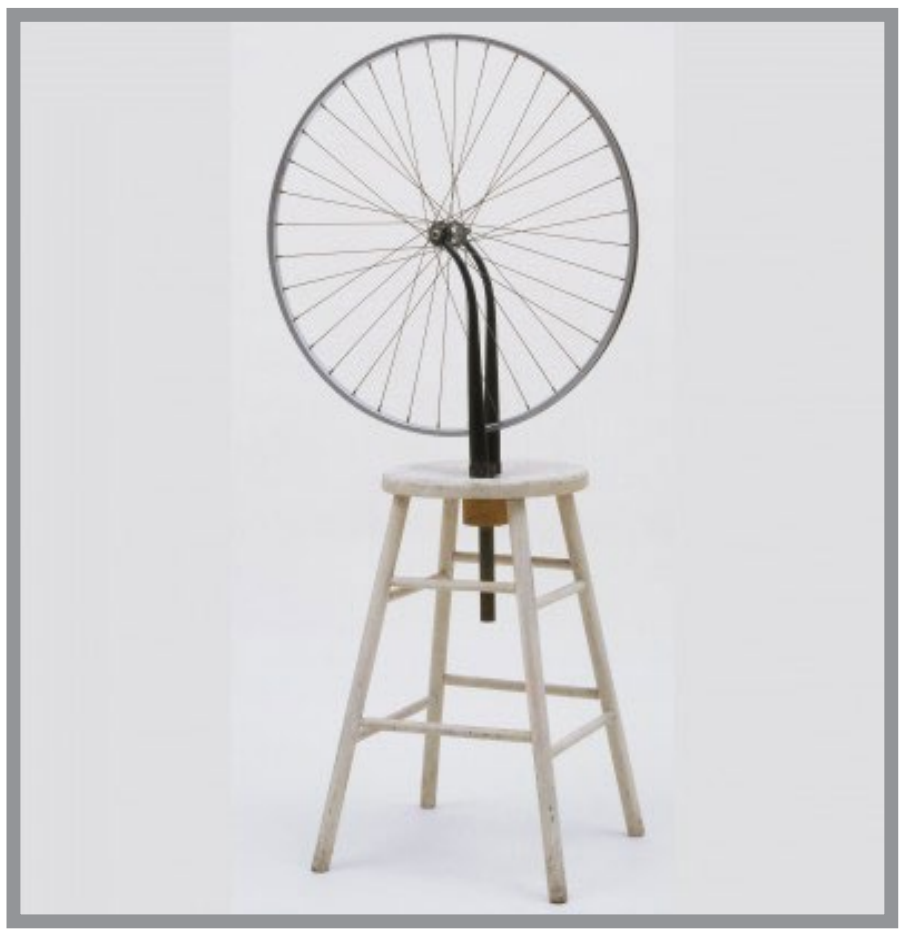

FIGURE 5: Bicycle Wheel (1951, third version, after original of 1913 was lost) by Marcel Duchamp (Public Domain).

When Bicycle Wheel was first displayed, Duchamp invited viewers to spin its wheel, because "To see that wheel turning was very soothing, very comforting ... I enjoyed looking at it, just as I enjoy looking at the flames dancing in a fireplace."59

Well, is this art? Perhaps this is not the question to ask. Instead: does it create new meaning? Beauty is in the eye of the beholder. So is meaning - meaning is in the eye of the beholder. The chair no longer functions as chair, but now as a foundation for a new object. The bicycle wheel is utilised surprisingly, no longer touching the ground. It is turned exactly upside down, now facing upwards - as what? Is it flames flickering in the fireplace? An eye to the future? An antenna into another world? Or, is it simply ... a used bicycle wheel, mounted on an old chair?

We could indeed tinker with this, with these 'meanings'...

To 'tinker' means to 'play'. 
Of course, the notion of play is not new in theology. The Scriptures already speak of wisdom that played like a child before God at the eve of creation. ${ }^{60}$ Many philosophers, such as Hieronymus, Origines, Gregory of Nyssa, Maximus and other mystical theologians, represented a theology that functioned as opposition to the official (strongly dogma-oriented; onto-theological) tradition of their times. These often-underestimated movements contained a passion for rediscovering the human being as homo ludens, as a playing and playful creature, a co-worker in unity with the playing and playful God (Deus ludens). ${ }^{61}$

In playing, we learn to deal with the incongruences of life. We do not take our notknowing too seriously. We are as already suggested, far too serious, far too joyless in our search for truth and meaning. Our incapability to play reveals our disbelief in the work of the Spirit. We do not trust the Spirit to open new, unknown mysteries to us. Our sermonic efforts and synodical statements and theological constructs are probably so boring for this very reason.

In my opinion, Christians - and particularly theologians - are, or should be, 'bricoleurs', rather than security guards, patrolling along the borders of ecclesial dogma; 'tinkerers', playing with perspectives, rather than theological killjoys. We should be bringing chairs and bicycle wheels together in an innovative fashion rather than trying to produce eternal dogmas and tinker-free creeds.

However, being a bricoleur does not equate superficial joy. Tinkering does not imply perpetual frivolity. Play is not always necessarily pure pleasure. On the contrary, play can be painful; tinkering may take place through tears; and bricolage might be needed within, and against, the bitterness of life.

My son already knew this, at the age of fifteen. In grade 10, during art (pottery) classes, they had to create something around the theme: speaking, silence, and truth. His version was a head-and-shoulders piece, which to this day has not given away all its secrets. ${ }^{62}$

The mouth is gagged, seemingly stitched up - but it is in a way still smiling, still speaking. The eyes are closed up, but somehow one senses that it is still looking at, through you. The eyepatches are a cross and a diamond, reminiscent of what? The Cross of Christianity, and the Ace of Diamonds on a deck of cards? If this would be the case, the figure is looking at the beholder, and life, through the Cross' lens and a card game's lure.

60 Proverbs 8:30.

61 See my discussion in Johan Cilliers, 2004, The Living Voice of the Gospel: Revisiting the basic principles of preaching, Chapter 2.

62 It still holds an honorary place in my study. See also the depiction of my (former) office, discussed earlier on. 


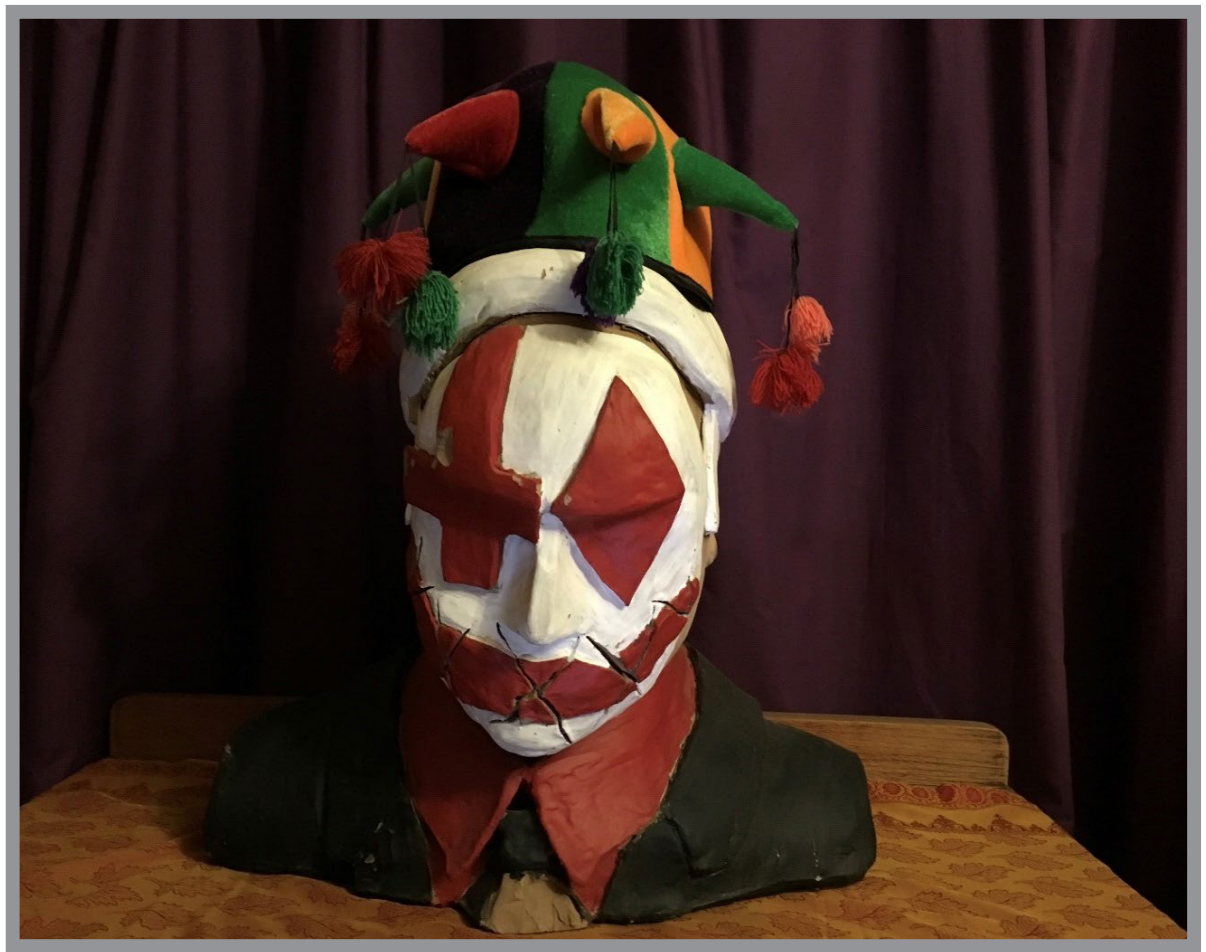

FIGURE 6: Speaking, silence, and truth (2005) by Jacques Cilliers.

The carnivalesque character of the figure cannot be missed - underlined by the motley (which, admittedly, was a later addition). The figure is silent, but speaking; blindfolded, but seeing. Black and white are held together, by red. The expression is serious, and yet, clownish. Its looks can fool you - bricolage, in clay, against the bitterness of life; tinkering with 'truth', through tears.

It says: 'truth' cannot be silenced, nor hidden away. It continuously speaks up and continuously comes into vision. Perhaps you do not hear or see it. It might be the apex of foolishness for you, but it is there; it is here - amongst us. Those who hear and see it might be labelled as fools and clowns. But they do see, and they do hear. ${ }^{63}$

Obviously, my son is quite clever. He holds three degrees in Ancient Studies and Marketing. Enough said.

At this point, let us allow ourselves to be interrupted again. A wise man, called Teacher, or Leader of the Assembly, speaks up. It is worth listening to him, even though he delivered this 'sermon' a long, long time ago:

63 For a theological discussion of 'foolishness', see Cilliers and Campbell, Preaching Fools. See also Chapter 2 on the art of seeing. 


\section{MEDITATIVE INTERRUPTION \\ SENSE UNDER THE SUN? \\ Ecclesiastes 1:1-11; 12:9-14}

One would probably not hail the Teacher (in Ecclesiastes) as the greatest optimist of all times. If a prize could be won for being the Most Inspiring Optimist of the year, do not go looking for his name on the shortlist. On the contrary, he is (seemingly) a pessimist without equal; the Father of all pessimists, without comparison. He seems to outclass all cynics and nihilists - also the so-called 'modern' ones.

No wonder, given the keywords in his thoughts (and in his sermon). To name only a few of his morbid expressions: 'futile'; 'chasing after the wind'; 'everything is meaningless. ${ }^{64}$ His whole worldview, his outlook on life, is carried and coloured by these undertones of pessimism, or should we say overtones of fatalism.

According to the Teacher, a deadly and deadening rhythm holds everything captive, and consequently, nothing is new in this world, no sense to be made or seen 'under the sun' (another one of his favourite expressions) ${ }^{65}$ Generations come and go; the sun comes up and goes under; the wind blows this way and that way; the rivers keep on flowing into the sea; people keep on talking and looking and hearing and never getting enough of it. In the end, what do you get for all your labour in this world? Nothing. Everything ends up as, and in, nothing. ${ }^{66}$

We hear the Teacher at his morbid best in his classic comparison of humans and animals:

Surely the fate of human beings is like that of the animals; the same fate awaits them both: As one dies, so dies the other. All have the same breath; humans have no advantage over animals. Everything is meaningless. All go to the same place; all come from dust, and to dust all return. Who knows if the human spirit rises upward and if the spirit of the animal goes down into the earth? ${ }^{67}$

Surely, someone who argues like this, someone who believes that the day of one's death is better than your day of birth and that those who were never born are the 
happiest of all does not value life too highly, and should indeed not expect applause or glamorous awards for his contributions to the 'power of positive thinking'.68

It is no surprise that many good and clever people in Israel of old were highly disturbed by the thought of this heretical sermon's inclusion in the canon, or in the collection of texts considered to be holy in those days. There was even a rabbinical school that warned people to be careful not to defile their hands by handling, or at least by reading any words uttered by this Teacher. Even though we do not know what exactly was meant by this, we can deduce that they were not overly excited by the thought of this piece of blatant pessimism being part of their holy scripts. Some stated that references to God were later just sprinkled here and there, to give some legitimacy to an otherwise unsavoury sermon. ${ }^{69}$

The so-called pessimism of this Teacher is even more so shocking, because it is not simply plucked out of the blue sky. No, he was a man of wisdom, and he also imparted knowledge to other people. He pondered and searched out and set in order many proverbs. This Teacher searched to find just the right words, and what he wrote was upright and sincere, his sayings like firmly embedded nails. ${ }^{70}$ What we hear here, are not the ramblings of a nobody, but the well thought-through meditations of a wise man. He did his homework meticulously, researching everything under the sun, scrutinising all of life in his search for meaning.

On an 'intellectual' level, he enriched himself and others with books and knowledge and schools of wisdom (we could say: universities). His conclusion?

For with much wisdom comes much sorrow; the more knowledge, the more grief. ${ }^{71}$

For the wise, like the fool, will not be long remembered; the days have already come when both have been forgotten. Like the fool, the wise too must die! ${ }^{72}$

Of making many books there is no end, and much study wearies the body. ${ }^{73}$

The Teacher's contributions to the search for meaning in life, though, did not end there. On the level of the 'judiciary', he was an important figure, not only reflecting on the meaning of justice, but also seeking justice for all, and then he discovered:

In this meaningless life of mine I have seen both of these: the righteous perishing in their righteousness, and the wicked living long in their wickedness. ${ }^{74}$

\footnotetext{
68 Ecclesiastes $7: 1 ; 4: 3$.

69 Ecclesiastes $2: 24 ; 3: 10,17 ; 5: 1,6$.

70 Cf. Ecclesiastes 12:9-11.

71 Ecclesiastes 1:18.

72 Ecclesiastes 2:16.

73 Ecclesiastes 2:12. Makes me wonder, why I am writing this book?

74 Ecclesiastes 7:15.
} 
His conclusion? As far as justice goes, this world is turned upside down. Therefore, one should not position yourself as being 'too' righteous, but also not as 'too' godless. ${ }^{75}$ Because this world is neither Heaven nor Hell, we should neither act as incarnated angels nor as incarnated devils. Rather, just go with the flow.

On an 'aesthetical' level, the Teacher made incredible contributions, to enrich (the meaning of) life. He actively supported the arts, the opera houses, the musicians of his day. ${ }^{76}$ He took part in every possible cultural expression, devised to relieve tension and promote relaxation amongst the people. He encouraged the creativity of architecture with the building of houses and the development of agricultural enterprises, with the construction of dams and the design of vineyards, gardens, parks, fruit trees and the plantation of young trees. ${ }^{77}$ His conclusion?

Yet when I surveyed all that my hands had done and what I had toiled to achieve, everything was meaningless, a chasing after the wind; nothing was gained under the sun. ${ }^{78}$

Then, there were his 'economic' achievements, too many to list. He became wealthy beyond measure, owning slaves by the dozen, cattle and sheep in their hundreds, and silver and gold worth millions. His conclusion? We can start guessing by now:

We leave this earth naked, as we came into it. We cannot take anything with us, not a thing for which we worked so hard. ${ }^{79}$

So, he tried 'leisure and pleasure' - drinking wine, enjoying the company of countless beautiful women. He did not abstain from a single pleasure that life has to offer and concludes, yes, you got it:

"Laughter," I said, "is madness. And what does pleasure accomplish?"

These conclusions of the Teacher disturb the peace of so-called modern society, stir the waters of our self-made tranquility. For, it is exactly in the things in which he finds no meaning at all that we so devotedly search for meaning. Our society has, to a large extent, fallen prey to the calling of the gods of intellectual, economic, and technological achievement and performance. Our marketing machinery proclaims glowingly: this product is new and unique - and you simply 'have' to buy it. With our prosperity mentality, we build our utopias, our worlds in which we believe we could live meaningfully and happily ever after.

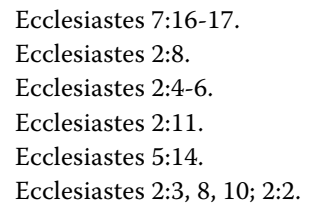


And the Teacher? With bold strokes, he draws a line across all our heated efforts to create 'meaning' in this world, calling it a futile chasing after the wind. Who can catch the wind? Who can hold even a light breeze between the fingers? Who can grasp the gale-force of the storm? The Teacher unmasks our society as being 'driven', yes, but by what, and for what? A 'rat race', of which a victory is meaningless? $\mathrm{O}$ yes, you may win the race, even convincingly so, but once you have crossed that finishing line, you will discover: I am (still) a rat.

So, how should we then understand, or even appreciate, what this Teacher is saying? It is not for nothing that his words were, in the end, taken up within the ranks of the 'holy texts'. Or should we keep our hands clean and avoid it altogether?

Perhaps a comparison with another piece of wisdom, also found amongst the holy texts, could be helpful. The character called Job is sitting on the ash-heap, stripped of all the gifts of the Giver. All that he has left is a skin disease, a piece of pottery to scratch himself with, and a nagging wife. ${ }^{81}$ All the things that should have made his life happy and meaningful are gone. Job seems to have found the Giver of the gifts. Above him, the heavens are open when he confesses: "The Lord has given, and the Lord has taken away. Bless the name of the Lord." ${ }^{82}$ He seems to have found meaning within meaninglessness.

The Teacher, on the contrary, have all the gifts that the Giver could hand out - health, wisdom, wealth, and much more. He literally 'has it all', possesses everything 'under the sun. He finds no meaning in all of this, after trying out all of it. He seems to lack the Giver of these gifts - as opposed to Job. Above him, the heavens are closed up, solid as an unbreakable copper dome. He misses out on the meaning that can be found 'above the sun', with God. Under the sun, nothing makes sense to him. $\mathrm{He}$ seems to have found meaninglessness, without 'meaning.'

Probably this comparison does not do justice to the Teacher. Because, strangely enough, his 'final conclusion' is not that of a cynical 'acceptance' of meaninglessness. No, he storms at the solid heaven above him; he keeps on knocking on the seemingly unbreakable copper dome. In a sense, his whole sermon is a cry from 'under the sun', to the world 'above the sun'. His sermon constitutes a cry for 'advent' to take place, a cry for the heavens to open, bringing 'meaning' to life.

We could say: in this sermon, we find a twofold approach to the quest for the meaning of life; and consequently, a two-pronged take on trust. On the one hand, a complete mistrust towards everything under the sun, knowing that no meaning can be found there. On the other, a flight towards God beyond the sun with complete trust, knowing that meaning can be found there, and only there. The Teacher has indeed learned, after trying everything, to look elsewhere in his search for meaning.

\footnotetext{
81 Job 2:7-9.

82 Job 1:21.
} 
In retrospect, we can discover this flight towards God, this cry for advent, throughout the sermon, like hatches being opened to let in the light. ${ }^{83}$ These hatches, being opened towards heaven, represent far more than added on efforts to give at least some form of legitimacy to an otherwise unsavoury sermon. On the contrary, it is indicative of the Teacher's understanding of and the quest for, meaning.

Perhaps we see such a hatch thrown open in the 'conclusion' the Teacher reaches towards the end of his sermon:

Now all has been heard; here is the conclusion of the matter: Fear God and keep his commandments, for this is the duty of all mankind. For God will bring every deed into judgment, including every hidden thing, whether it is good or evil.84

Well, one could ask: Is that it? Is that all? For some, this might not be a comforting conclusion at all. After all, it contains words like 'fear,' 'commandments', 'duty', and worst of all - 'judgement'. For some, this light shining down the hatch from heaven might seem not to be benevolent, but blinding, like a spotlight penetrating our every move and deepest motives. Does the 'meaning of life' entail, ultimately, living under constant scrutiny, being watched over by some cosmic, judgemental Eye? Would this not deepen our sense of dread in life even more?

If we understand the Teacher in this way, we have misunderstood him. On a first level, he reminds us, living 'under the sun', that there is an 'above the sun.' The cosmos is not cold and empty, devoid of all compassion. On the contrary, we live in a moral universe, in which we cannot simply make and break as we wish. All our actions will be judged, but by a righteous, and exactly on those grounds, compassionate God. Perhaps we should turn this around: on the grounds of God's compassion, God is righteous. God should be feared, i.e. approached with gratitude and praise - and we do this by living according to the commandments, given to guide us in all our doings 'under the sun'.

The Teacher's 'conclusion' underlines the fact that life 'under the sun' is connected to life 'above the sun'. When we deny this connection, we become stuck in meaninglessness. When we accept this connection, when we open the hatches to let the light shine in, or better: when we start crying out for this to happen, we are like sunflowers. We all know that the 'meaning' of a sunflower's existence is, well, the sun. The name already says it all: sunflower. In looking away from itself, in lifting its head towards the sun, the sunflower finds its destiny. If for some reason, the sunflower should look away from the sun, it collapses into itself, and withers and dies.

May I interpret the Teacher's sermon in this way, knowing well that all metaphors are limited? According to the Teacher happiness and meaning are given when you look away from yourself, towards God. In this way, you reach your destiny. Sin, on 
the other hand, pulls us down into meaninglessness, causes us to become curved into ourselves (homo incurvatus in se). We may think that we are flourishing, but we are collapsing. Then we no longer are sunflowers, but sin-flowers.

The Teacher has discovered that 'meaning' is to be found with, and through God, and God alone. Nothing else satisfies, not in the long and, more often than not, also not in the short term. Therefore, the Teacher is crying out: Lord, open the seemingly solid heaven! Come to us and enter our lives! Come, Lord, and be with us 'under the sun'!

Amazing. Is this not exactly what happened? Advent (the coming of Jesus) did take place. The Word did become flesh, to dwell amongst us. ${ }^{85}$ God did come 'to be with us' and to bring meaning to life, not as a quick fix, not as another product advertised as indispensable for happiness. This message is the good news, the gospel, that does not simply substitute pessimism with so-called 'optimism'.

The meaning and hope that the coming of God creates is something completely different than the promises that operate in optimism or are broken in pessimism. The promise of God is of a different order; it points towards a lifestyle of saying: Even if ... there is nothing, even if I am Job, covered in ashes, yet, I will glorify God - which sounds very much like what another wise man, the prophet Habakkuk once did. ${ }^{86}$

This wisdom represents a stance that says: I will live 'as if' ... God is faithfully present, 'even if' I experience the contrary. Why? Because God is present. It also lives with this 'as if' 'even if' stance when you are surrounded by health, wealth, and luxury. This wisdom-that-seeks-meaning moves within all the tensions and pleasures of life 'under the sun'.

The Teacher is not a pessimist, and he is also not an optimist, at least not in the popular sense of the word. I would not even call him a realist, but an Adventist - but not in the denominational sense of the word. The Teacher is crying out and seeking for the coming of God. He mistrusts everything under the sun, and he trusts God, beyond the sun.

Earlier on, we called this a twofold approach to the quest for the meaning of life; and consequently, a two-pronged take on trust. Let me now add a third dimension. There are three movements taking place in the Teacher's sermon: a move away from yourself; a move towards God, and then, because God moves towards us, a move back 'into' life. ${ }^{87}$

Let us understand this: the Teacher is not demeaning wisdom, or justice, or economy, or art, or culture and technology. What he does, however, is to point out, in no

85 John 1:14.

86 Habakkuk 3:17-19.

87 In a sense this is typical of Old Testament cosmology and wisdom: if you view life from 'beneath to above', life seems meaningless. All you see, is the dome of heaven covering the earth. If, however, you view life from 'above to beneath', through the lens of 'fearing God', life becomes new and meaningful. 
uncertain terms, that meaning cannot be deduced from these things, but meaning can and should be given to these things because God comes to these things. He is not demeaning, rather re-meaning. Sounds a bit like the approach of Victor Frankl, does it not? The meaning of life is to give meaning to life; we could add, because God has given, and gives meaning to life.

The Teacher sounds like the world's greatest pessimist, but he is not. Listen, for instance, to these utterances:

I know that there is nothing better for people than to be happy and to do good while they live. That each of them may eat and drink, and find satisfaction in all their toil - this is the gift of God..$^{88}$

And:

This is what I have observed to be good: that it is appropriate for a person to eat, to drink and to find satisfaction in their toilsome labour 'under the sun during the few days of life God has given' them - for this is their lot. Moreover, when God gives someone wealth and possessions, and the ability to enjoy them, to accept their lot and be happy in their toil - this is a gift of God. ${ }^{89}$

Just to make sure we heard him clearly:

So I commend the enjoyment of life, because there is nothing better for a person under the sun than to eat and drink and be glad. Then joy will accompany them in their toil all the days of the life God has given them under the sun. ${ }^{90}$

This is the Teacher at his best. For him, there is no (longer any) discrepancy between gifts and Giver, none whatsoever. Here, 'under the sun' (repeated twice), gifts are celebrated and enjoyed as coming from the Giver; and the Giver is praised as the One who grants these gifts for our enjoyment and celebration.

Amazing. On the one hand, we hear words like meaningless, futile, senseless, nothing, chasing the wind, etcetera, flowing from the mouth of the Teacher. On the other hand: happiness, enjoyment, joy, satisfaction, gladness.

This Teacher is no longer chasing the wind; rather being uplifted by it.

This Teacher is not moaning about the meaninglessness of life; instead, advocating an enjoyment of life that gives meaning to life.

Perhaps the Teacher would have approvingly nodded if he saw a depiction called The Joy of Life, painted many centuries later. ${ }^{91}$ When looking at this depiction, one

88 Ecclesiastes 3:12-13.

89 Ecclesiastes 5:18-19.

90 Ecclesiastes 8:15.

91 In this painting, Pablo Picasso explores the imagery of Mediterranean mythology - nymphs and fauns, satyrs and bulls, wine, music and dance, in a fascinating manner. 
senses that it does not minimise, or bypass, the complexities of life - on the contrary. Somehow, it explodes with life, in full and bright sunshine; explodes with the joy of life, under the sun. We see people and animals exuberantly dancing and playing musical instruments; we see blue seas and ships taking us to new spaces and places; we see the yellow sands of the beach, inviting you to wriggle your toes in it ... Perhaps I should say no more. Look for yourself:

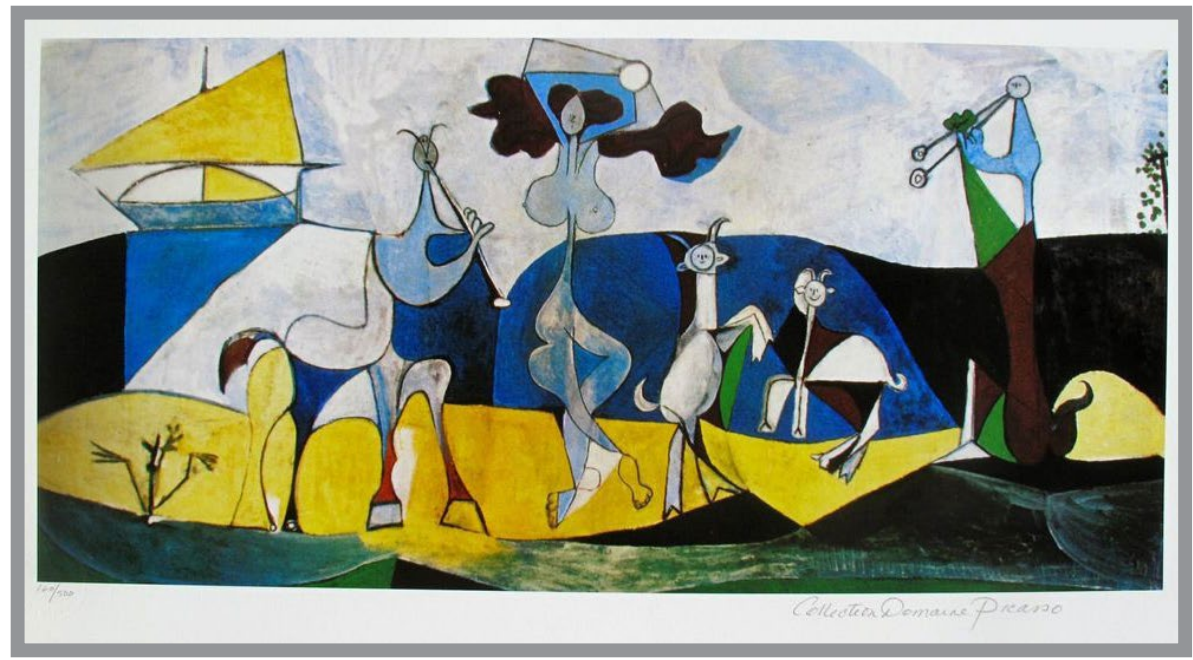

FIGURE 7: La Joie de Vivre - The joy of life (1946) by Pablo Picasso (Public Domain).

Does this depiction not celebrate, as does the Teacher, the fact that 'I am here now'? Are the gifts of life, space and time, of being and becoming, not to dance about? Does grace not provide the music? 


\section{Chapter 2 \\ GRACE: \\ TO KNOW THAT YOU WILL KNOW, FULLY}

Where do we come from? Gauguin's painting asks, as well as: Where are we going? As fascinating as questions about our origins are, so are questions about our future, and perhaps even more. Futurology seems to be alive and well, pondering the tensions between what is possible, predictable, and plausible. Who on earth knows what is going to happen on earth?

I would suggest that at least the following three areas will be the centre of attention: ecology, technology, and the reality of global catastrophes - and these issues will all be somehow connected. One needs no imagination to understand that various life forms are currently being threatened on planet earth, up to, and beyond the point of extinction. One needs no special insight to know that the ever-accelerating developments in technology are indeed only the beginnings of breath-taking technological advances that will irrevocably shape our future. Sadly enough, even a minimal level of intelligence is needed to realise that humanity will be facing global, catastrophic challenges in the future, on biological, social, military, political, and many other levels.

Writing this book in the year 2020, I suspect that most of planet Earth's future will be played out in the triad of ecological challenges, technological developments, and global catastrophes. Perhaps we will, after all, not achieve the Utopia of flourishing and well-being, so much desired by so many. On the contrary.

The question then is: would life have any 'meaning' if we were surrounded by scenes of devastated, post-apocalyptical surroundings, and haunted by the ruins of a scorched and squandered earth? Would life still make 'sense' if we were globally connected with brilliant technology, but we have to avoid any human contact because of the threat of ever-present viruses that could spell out our very end?

What would be the use of having so much breath-taking medical expertise at our disposal, if we cannot stop the spread of unknown diseases, or at least do so only after substantial human sacrifices and devastating global panic? What does 'life' mean when microbes so small that you cannot see them, are everywhere, more powerful (and threatening) than any so-called 'powerful', political figure or institution?"

92 I write these words during a national, South African "lockdown" because of the COVID-19 viral outbreak, following the global lockdown in most countries on our planet, with strict rules concerning "social distancing", in an effort to slow down the destructive path of the seemingly unstoppable virus, for which 
What does the 'meaning of life' entail when thousands, no millions of people are snuffed out like insects through global catastrophes such as famine, wars, diseases, and natural disasters? Did any of those snuffed-out lives really 'mean' anything? Or were they merely small, insignificant blobs of 'being', minute instances of living plasma, mere guinea pigs in some cosmic experiment or plot to demonstrate what 'life' means, or could mean?

So, where are we going? Well, one answer would certainly be death. Collectively and personally. Eventually and inescapably. Certainly and irrevocably. No matter what happens to the ecology, or the technology, or the looming catastrophes. Death. And beyond that?

Since the dawn of time, almost all religions offer answers to this haunting question. One rather functionalistic answer to the role of religion in the face of death, or all threatening experiences on the borders of life, has been labelled: managing (i.e. overcoming) our existential experiences of contingency. The German theologian Arnold Gehlen called it Kontingenzbewältigungpraxis. ${ }^{93}$

According to him, religion played a specific role in pre-modern times, in particular on three levels: First, by offering what could, in hindsight, be called a 'theoretical' attempt to clarify the meaningful inter-connectedness of the whole of reality, in terms of its origins and future. Second, by propagating a type of morality that was intended, on a 'practical' level, to control how people acted or should act, through education, dogma, example and tradition. Third, by offering the function of Kontingenzbewältigung, i.e. by helping people to cope with the uncertainties and unplanned catastrophes of life, particularly in existential border-of-life experiences (he calls it: Rückseite des Lebens - the backside of life). ${ }^{94}$

According to Gehlen, modern society has, to a large extent, taken over the first two roles of religion: the theoretical ordering of life and the practical regulation of ways of living. Although modern technology plays a major part in alleviating the contingencies of life (the third role ascribed to pre-modern religion), it cannot completely do so, and hence the continued importance of religion. This - to face the negative happenstances of life - remains the core of (current expressions of) religion, speaking from an anthropological point of view..$^{95}$

Religion - also Christianity - helps us towards this end. It incorporates all (anthropological) endeavours that serve our well-being as humans. Of course, this is important but, in my opinion, that would not be the sum of it. Christianity signifies more than a coping mechanism, projected from the ingenuity of our religious

no vaccine has been found, at least up till this moment in time (24 March 2020). Are these experiences of forced quarantine forebodings of what is to come? See also the discussion in Chapter 1.

93 See Arnold Gehlen, Urmensch und Spätkultur. Philosophische Ergebnisse und Aussagen, $66 \mathrm{ff}$.

94 Ibid., 31.

95 Ibid., 75. 
make-up. There is a 'more', a 'beyond'. Let us call it, following Paul's thought, the future of our 'full' knowledge:

Now I know in part; but then I shall know fully, even as I am fully known. ${ }^{96}$

A remarkable thought. Our current knowledge will be changed fundamentally. Our ultimate goal before, in, and after life is to come to the fulfilment of knowledge of life. Paul uses a truly stunning expression: 'even as' we are known now, we will fully know. ${ }^{97}$

'Even as'. Does this mean we will, 'even as' God does, look across and through the universe and all that was, is, and ever will be - with full understanding? Mindboggling. Will there be some comparison, some analogy, between our knowledge and God's knowledge? Incomprehensible - for one only know partially, now.

The future is the future; it is not 'now', and yet we are granted and do have glimpses of the knowledge to come, now. We do sense the fullness, and fulfilment of grace-filled knowledge, of eternal 'knowledge, immersed in love. ${ }^{98}$ Could this be understood outside the scope of grace?

Having 'glimpses of the knowledge to come', now, could also be called 'instant as eternity. ${ }^{\prime 9}$ All three words in this phrase are important. 'Instant' signify temporality, and therefore history. In instants, events - instances - take place. 'Eternity' on the other hand, denotes the 'beyond' of timelessness. 'As' implies a correspondence, a comparison, even an identification: instant is eternity, and eternity is instant. Therefore, in the same breath, 'instant as eternity' could also be called 'eternity as an instant'.

In temporal discourse, we traditionally speak of past, present, and future. We could say: we come from the past, and we are on our way to the future. The present is seen as the time frame 'between' past and future. Past, present, and future should, however, not be seen as separated 'episodes'; should not be compartmentalised into temporal fixations. Such an endeavour would not only distort our views on past or future but particularly on the present. The present is inundated by the past and the future, but also carries within itself glimpses, i.e. 'instants as eternity'. As such, it aids us in answering the question: Where are we going?

Could we spatially express this, knowing full well the limitations of this endeavour? The present is not only linked 'backwards', to the past; it is not only linked 'forwards', to the future - it is linked, as (or in) an instant 'upwards', with the 'beyond', with eternity. For us to discern, see and therefore experience this, we need a specific type of eye, a glance, a glimpse - of the knowledge to come.

961 Corinthians 13:12.

97 Cf. Arnold van Ruler, De meeste van deze is de Liefde. Het hart omvat de dingen en heeft ze lief, 83.

981 Corinthians 13:7-8.

99 I borrow this phrase from Søren Kierkegaard. See the discussion further on. 
It is interesting to note that 'instant' or 'moment' is linked in many languages to seeing, to the eyes. In Danish, it is Øjeblikket - a glance of the eye. In German, it is Augenblick - a blinking of the eye. In Dutch and Afrikaans, oomblik and oogwink also denoting a brief moment, as short as the blink of an eye. It seems that 'moments' and 'instants' are there to be seen, but pass by quickly, and could easily be missed.

Even more disturbing: instants could pass by, as 'eternity' (i.e. as 'future') - and you have no eye for it. You could wink your eye, and not notice eternity winking, calling and inviting you. Eternity could pass you by, in the blink of an eye, but you do not see it, because you have eye-blinkers on. It seems much, perhaps all, depends on your vision; on how you have mastered, or not, the art of seeing.

Of course, we live in a world that views a lot. We seem to suffer from what might be characterised as 'visual overload' or hyper-visuality: “... we have so much, but see so little", according to Stephen Pattison. ${ }^{100}$ We have all the instruments necessary to aid the eye: "With the extension of sight by microscopic, telescopic, electronic, digital and other means symbolised by instruments such as electron microscopes, scanners, cameras and photographs, we are all too aware of living in a world structured around [the] sight and the visual." ${ }^{101}$

Yes, we have all the instruments to aid the eye, but we seem to have lost the art of the eye. It is only through the art of the eye that we can decipher 'signs of the transcendence' even, and particularly in everyday life. ${ }^{102}$ We need to cultivate a 'haptic vision', which focuses on a person-like connection to the seemingly mundane things of life like crash helmets, toasters, etcetera, rather than simply essentialising or functionalising them. ${ }^{103}$ We need to revision reality, as representations of the presence of God, even - in the words of Martin Luther: "... as the masks that God is wearing, and the clothes God has on."104

So, do we see where we are going?

We are going 'into' eternity, in each everyday space that we enter, and in each instant that we call 'now'. Now 'is' the future, and the future 'is' now. Or, to put it in other words: our lives are a synthesis of the temporal and the eternal. We, however, tend to miss out on the eternal, because we simply do not see (even if only having a glimpse of) eternity. We tend to spatialise moments in time, and thereby the infinite

100 Stephen Pattison, Seeing Things: Deepening Relations with Visual Artefacts, 1.

101 Ibid., 3.

102 Birgit Weyel, 2007, Predigt und Alltagskunst. Wilhelm Genazino und der poetische Blick auf das Leben, 209-211.

103 Pattison, Seeing Things, 17.

104 Martin Luther often spoke of God's acts and presence in history as a disguise, or mask. According to Luther, every part of creation form part of God's masquerade - Ideo universa creatura eius est larva dei. God is always present and always working. Not only did God create this world; the creation also represents God, and could be compared to a cloth, with which God is covered. Luther, 1883:40(1):174, 17(II):192. 
succession' of time, i.e. the instant of linkage between the present and eternity, is brought to a standstill.

In his inimitable manner, Søren Kierkegaard pursued this thought, stating as follows:

The present is the eternal, or rather the eternal is the present, and the present is full ...

Thus understood, the instant is not properly an atom of time but an atom of eternity ...

The instant is that ambiguous moment in which time and eternity touch one another, thereby positing the temporal, where time is constantly intersecting eternity and eternity constantly permeating time ... The concept around which everything turns in Christianity, the concept which makes all things new, is the fullness of time, is the instant as eternity, and yet this eternity is at once the future and the past. ${ }^{105}$

Time - the present - is not only, or even primarily, the atoms of moments continuously fleeting by; it is the instants as eternity, continuously breaking in - into the present.

I would call these instances as eternity, continuously breaking in grace. In its fullness. Grace, upon grace.

With this, I do not have a nebulous, 'time-less' abstraction in mind. Grace, upon grace, continuously breaking in as instances as eternity, is given to us through Christ. ${ }^{106}$ In the fullness of time, the 'Christ-instant' took place, his birth, death, resurrection, and ascension - and it keeps on taking place in each instant as eternity, continuously breaking in, in the present, as grace, upon grace. We are not so much moving 'forward' - towards a future (that of course, also), as we are moving 'into' Christ. All of creation is continuously underway, 'into' the ultimate fulfilment in Christ. All that was, is, or will be, is continuously converging towards this 'pleroma', this fullness, this final unification of all things - in the Cosmic Christ. ${ }^{107}$

I speak about the 'Christ-instant', and this needs some further clarification. Christ's birth, death, resurrection, and ascension were all historical, i.e. temporal events. They were simultaneous 'instants as eternity' that took, and continue to take, us 'into' Christ.

Normally, when we speak about our 'being', particularly scientifically and philosophically, we use the term 'ontology'. The word 'ontology' is a compound word, made up from 'onto' (from the Greek övто - being; that which is), and 'logia' (from the

105 Kierkegaard calls this fullness of time 'the instant', following the Danish Øjeblikket - 'a glance of the eye'. In Latin the word for temporal is momentum (from movere), which expresses the vanishing of time - in an instant, i.e. in a twinkling of an eye, as the Apostle Paul declares concerning the passing away of the world (1 Corinthians 15:52). This means, according to Kierkegaard, that "the instant is commensurable with eternity, because the instant of destruction expresses at the same time eternity". See the fascinating discussion in Søren Kierkegaard, The Concept of Dread, 77-81.

106 See again the discussion of John 1:16-17 in the introduction to this book: "For from his fullness, we have all received, grace upon grace. For the law was given through Moses; grace and truth came through Jesus Christ." This Christ-instant not only inspired the title of this book, but also underlines its basic structure. See the contributions of Teilhard de Chardin in this regard. Obviously, I cannot do justice to the richness of his theological and philosophical thought here. His thoughts on the relationship between evolution, science and faith can be read in his 1977 book, Christianity and Evolution. 
Greek $\lambda$ oyía - logical discourse). In terms of our 'being in Christ', I would prefer to use the word 'intology'.

The notion of intology seems to resonate with the 'network culture' - where everyone and everything (all known knowledge) are brought 'into' a new, technological realm. ${ }^{108}$ The word 'into', if traced back to the Greek version of it ( $\varepsilon i \varsigma)$, indicates notions like the entering of place and time; fulfilling a purpose; reaching a result; etcetera. It means 'motion into which', implying 'penetration' ('unto', 'union') given a particular 'purpose' or 'result'.

In my use of 'intology', it is not so much about the philosophical and scientific reflection on (i.e. ontology of) the meaning of 'being' (although this is not excluded), as it is about the infinite instant(s) of being taken 'into' Christ, of being 'in' Christ.

I realise that the notion of 'into' or 'in' has its limitations, being a spatial and, therefore, temporal concept. Perhaps that is exactly the point: eternity does not bypass time and space, but simultaneously penetrates and transcends them - 'as' eternity.

These 'instants as eternity' could, in my opinion, be understood on at least three levels. First, not only has God entered our space through the incarnation of Jesus, but we have also entered the space of God through the resurrection and ascension of Jesus. Our suffering is taken up 'into' Jesus; it has become part of God's Being. God bears our suffering in such a way that it becomes part of who God is. God is vulnerable, carrying our suffering in God's Being. We no longer carry our vulnerability alone.

No soft-soaping or romanticising of suffering is intended here, no usage of sugarcoated phrases like: "God came to pick the most beautiful flower in God's garden", or "God chose those whom God knew would be strong enough to carry the suffering". Who wants to be picked from life, even as the most beautiful flower, anyway; and who wants to be treated, through painful experiences, as an example of extraordinary, devotional strength?

All the suffering, all the unsolved mysteries connected to human suffering, all the global catastrophes that have struck and continuous to strike this planet, and each individual on earth, are taken 'up', taken 'into' the history, i.e. the Being of God. Auschwitz becomes part of the 'DNA' of God; Hiroshima becomes part of God's 'anatomy'; each COVID-19 victim, dying for lack of breath, becomes part of God's 'history'; each child, dying of hunger, becomes part of God's fibre, crying out for nurture and compassion. Each beggar, knocking at my door, becomes a face of God - which I shun, more often than not.

The notion of intology, however, has a second dimension. Not only is our suffering taken up into God's Being; God's future is also brought 'into' our present. Our space in time and our time in space become filled with future, with the novum of God's 
intent to bring our space and time to fulfilment, to the triumph of God's telos. God is present as the Vulnerable; God is also present as Fulfilment. ${ }^{109}$ This present - this instant as eternity - indicates a space and time between vulnerability and fulfilment; fragment and fullness; incompleteness and telos - indeed, indicates the in-between spaces and times of the paradoxical present (praesentia paradoxia), which is characteristic of the synthesis of the temporal and the eternal. ${ }^{110}$

This means that, although our suffering is taken 'into' God's Being, and although God's future is brought 'into' our present, we have no control over these movements, just as we have no control over God, and just as we cannot manipulate grace. We cannot encapsulate, or capture, God or God's grace in any 'iron theology', or ecclesiological creed, or dogmatic 'statue', erected through some synodical proclamation, with the intent that it should last forever. ${ }^{111}$

Perhaps we could even state with Michel Serres, the French philosopher, that there actually can only be one, 'eternal statue' in history, a statue that deconstructs all other statues, and that is the empty tomb of Christ. Christ's movement from death to life transforms all statues into stones, rolled away from their fixed places. The resurrected Christ now moves through life, granting us instants as eternity, in which we receive the grace of being brought 'into' this Christ. ${ }^{112}$

Third, and importantly, being brought 'into' Christ in no way means that we are taken 'out of' life. Intology does not negate ontology but brings it to fruition. We are brought 'into' Christ so that we are (once again) taken back 'into' life. Intology means being 'in' Christ in such a manner that we are 'in' life, fully and truly. After all, Christ came so that we could have 'life in abundance', not in view of 'a pie in the sky' but the joy of life - eating and enjoying our daily bread, given by the Giver on this earth under the sun. ${ }^{113}$ We are brought back 'into' life, so that we can dance with the joy of life, to the tune of grace.

So, where are we going?

For myself, I found some answers in a theme that I have painted in many versions during many years - not knowing initially that this was an expression of my search for meaning in life. This painting (on the cover of this book) could be interpreted in other ways, than what I propose here:

109 Johan Cilliers, Seeing, Sighing, Signing contours of a vulnerable homiletic, 1-13.

110 Cf. Johan Cilliers, Between Fragment and Between Fragments and Fullness: Worshipping in the in-between spaces of Africa, 1-6.

111 For a discussion of 'Iron Theology', see Cilliers and Campbell, Preaching Fools, 44ff.

112 Michel Serres, Statues: The Second Book of Foundations, 226.

113 Cf. John 10:10. 


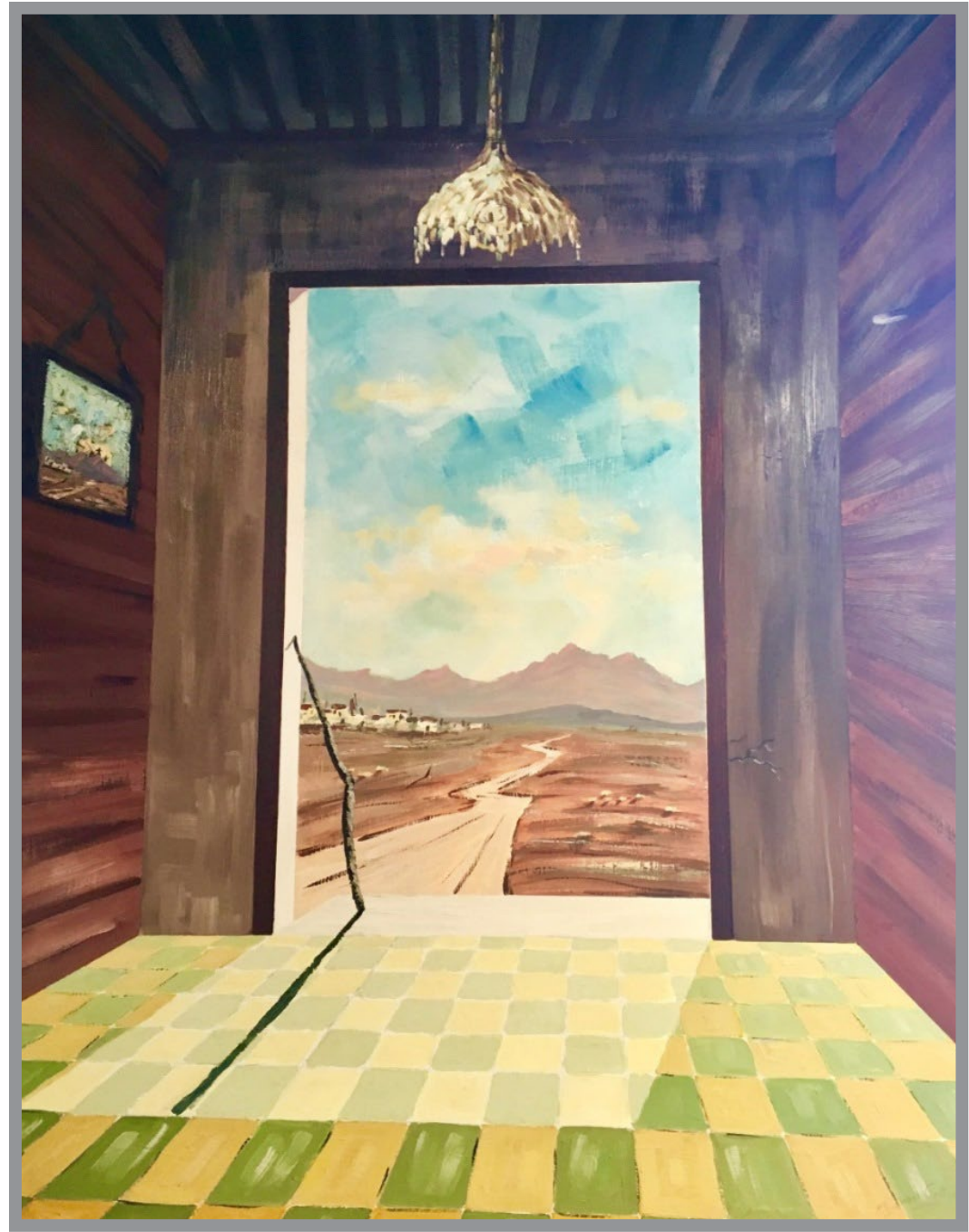

FIGURE 8: Into Life (2001) by Johan Cilliers.

On a first level, this depiction simply expresses my longing to return to my origins, a place called the Karoo, situated in the central part of South Africa. It is a semi-desert, arid part of the country, with wide open spaces, breathtaking sunsets, and awesome (I do not use this word lightly) night skies, with the moon and stars and Milky Way stretching brilliantly from horizon to horizon on a clear night - which happens to be most of the times, given the dry air.

On a deeper level, it illustrates that I, like everybody else, always wanted to 'escape' from certain things, take up my walking stick and start walking along the gravel road 
towards the distant mountains, stopping along the way to talk to the flocks of sheep (the major form of farming in the Karoo, also seen in the painting), coming to rest in the little town, inhabited by earthy, generous people. The room from which I am looking seems safe, but it still resembles a clinical space, restricting me from moving forward, or outward.

I wondered why I painted a single little pole, or hook, protruding from the right side of the wall? Nothing hangs from it. It seems to have no purpose, besides providing some perspective and shadow. Could it be an indication that nothing in this room (life) could be hung up, like a coat when you come home? I do not know.

Without the open door, this room would have been not unlike a jail cell. The sun shining in, creating its patterns on the floor, and of course the beckoning road and free spaces of the Karoo 'beyond' that, with the walking stick, waiting to be picked up, would not be there. Now, however, it holds the promise of moving out, of liberation, of coming home - elsewhere.

The painting symbolises the limitations (the room) in which I perpetually find myself - not necessarily an ugly room, even adorned with a chandelier, indicative of privilege, perhaps even luxury, compared to other 'rooms' in which people find themselves captured.

There is a deeper level, which I only in retrospection realise now. ${ }^{114}$ The experiences of being 'captured' between restrictive walls, and the 'instant' of picking up the walking stick and starting the journey and coming home, repeats itself throughout (my) life. We are perpetually taken 'into' life - and this happens in instants as eternity. The future (the distant mountains and town; 'The New Jerusalem'?) perpetually shines 'into' our experiences of captivity, as sure as the sun shines into the pictured room, underlining the fact that the 'future' is 'now'; and 'now' is the 'future'.

What does this 'future-now' mean? In terms of the structure of this book, I would say: to fully know - even if we know partially now. As already stated, this is, of course, paradoxical, but could we speak about this future-that-is-now in any other way? We continuously leave our enclaves, and walk down the road, exploring, not knowing fully, and continuously One comes towards us, meeting us on this road, beckoning us, and being with us in such a way, that our hearts are gladdened, and we see and know more fully, like so many Emmaus Pilgrims. ${ }^{115}$

What a thought: in such instants as eternity, we see 'even as' God does, with full understanding. And then we again find ourselves back within the parameters of our partial knowledge, longing to pick up that walking stick.

114 This painting was completed as a whole in 2001. At the time I had no knowledge of, or intention to, creating these interpretations that I am now conveying onto the painting. I now discover 'meaning' that has been hidden away, or rather, has been in plain sight all the time, waiting to be seen, in the blink of an eye. 
Let me put this in another way: the Presence of the Coming One (i.e. adventus) continuously takes place within the enclaves and enclosures of our life's rooms, already granting us the grace to step out on the road towards fully knowing. It might seem hidden away, but it is there, waiting to be discovered if one were to start looking for it. All that is needed, as Kierkegaard postulates, is the 'glance of the eye', the instant of looking, revealing this instant as eternity.

This 'key', a key that unlocks the door can also be seen in the painting above, hidden away in the miniature painting hanging on the left sidewall. On closer inspection, one sees that the miniature painting-in-the-painting is also a replica of the painting itself, but without the restrictive walls. Only the open road, flocks of sheep, distant mountains, and a small town can be discerned, the view of one that has already left the room, standing outside, on the road that leads 'into' life.

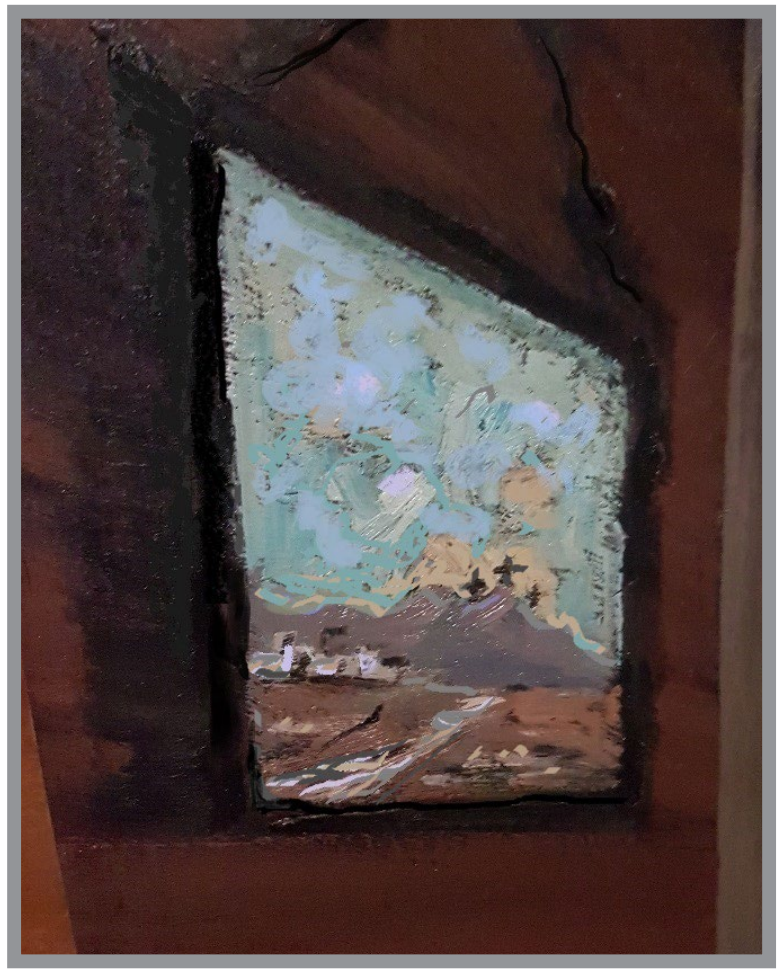

FIGURE 9: Detail: Into Life (2001) by Johan Cilliers.

The miniature is an impressionistic replica of the bigger painting (particularly the view outside the door), but there is also a difference. Closer scrutiny reveals three crosses on the distant mountain - reminiscent of the crucifixion of Christ, representing the 'Christ instant as eternity', the 'future-now' that has already opened, and continues to open the door, inviting us to walk 'into' our future. 
It is this Christ-instant-as-eternity that enables the light to shine in, to open the road before us, to hand us the walking stick. Blink your eye and look again: perhaps the walking stick is a reminder that we are part of the flock of sheep, grazing along the road, being guarded and guided by the Shepard's Staff? Perhaps it is this staff standing in the doorway, reminding us where, and to Whom, we belong - reminding us that we never walk alone.

It is true: we do not know what the future holds or brings, but we do know where the future is headed. Or do we? So often, we live in the expectation of things to come, things not to be trusted. So often, we have a mistaken sense of adventus - waiting for the wrong 'one' to come. I once heard about the following incident, perhaps too good to be true - or so good that it could only be true?

The people of a small town woke up one morning, and lo and behold, on every lamp post, a poster was placed, proclaiming the following:

\author{
HE IS COMING! \\ Saturday, 1 April \\ Town Hall: 7:00 p.m.
}

Nobody could say who posted this information, and the townsfolk started talking, speculating and, of course, gossiping. Was it some important politician, visiting our town? Perhaps the president himself? Or, perhaps a famous popstar? That would be great - given the fact that we are out here in the bush.

So, Saturday 1 April came, the people woke up, and to their amazement, all the posters were replaced with new ones, again covering all the available spaces for notices in town. This one read:

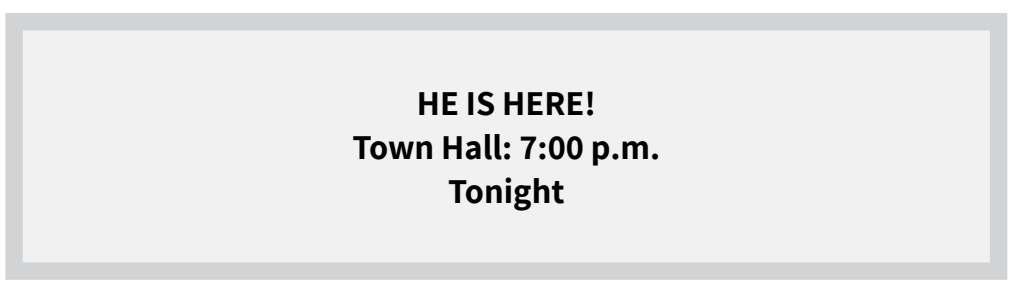

You can imagine the excitement, the buzz running throughout the community, heightened by the fact that nobody could detect, or would divulge, the source of this mysterious coming. 
So, an hour before the time, the town folks started flocking towards the town hall. Soon, it was packed. Expectation filled the air. After what felt like an eternity, the clock struck 7:00 p.m. The town hall darkened, a drum roll began, the curtains opened, painfully slowly - still dark. Then a spotlight came on, lighting up the stage.

The people gasped, some cried out, in disbelief, some swore. A few laughed.

On the stage was a poster, neatly fixed to an imitation lamp post, saying:

\section{HE IS GONE!}

That was all.

I do not know what the outcome of this narrative was, but I could imagine some possibilities, some serious, some frivolous.

Let us not go there. Rather to the vision of a Visionary, picturing the coming of One, whose appearance fulfils every expectation that what has been made new, will indeed be new. 


\section{MEDITATIVE INTERRUPTION \\ "I AM MAKING EVERYTHING NEW!" \\ Revelations 21:1-8}

On the 13th of May 1928, the German existentialist, Peter Wust, stood next to the grave of one of the most brilliant scholars of his times, the German phenomenologist, Max Scheler. Scheler was Wust's lifelong mentor, and Wust had the following to say:

Since I stood at the grave of Scheler, a new darkness has come over me. The mystery of death will not loosen its grip on me. Not that I fear death as such, no, it is something else. I am constantly wrestling with the thought [of] how terrible the moment of transition must be for everyone, the moment of transition from this world to the future one. If one could say that you lived your life completely in accordance with God's will, then this transition would certainly have been the most wonderful and blessed moment of our lives. Then it would be the birth-hour of our true, eternal existence. Because I have no doubt that eternity is filled with blessed light, and that our thirst for happiness will in the end be satisfied there [...] About all of this, I do not have the slightest doubt. But I have doubts about my own worthiness. I am uncertain about my own ability to endure on the road to the eternal future. Because in this regard, I am very poor [...] I also know that these doubts and uncertainties are wrong. Because not one of us is worthy, after all, to go to God. Everything depends on God's love, God's grace. This, and only this, carries me through to eternity.

Can this - that God's grace, yes, God's grace upon grace - carries us through death 'into' eternity, be said more clearly than in Revelations 21? Here we hear, for the first and only time in Revelations, the voice of God resounding from God's throne indicative of the fact that these words carry a particular weight; that they are as God declares, "trustworthy and true". ${ }^{116}$ What does the voice say?

"I am making everything new!"117

Could there be more comforting words than this? In the end, everything, yes, 'everything', will be made new - because everything has already been made new. This "will be ... has already been" tension is reflected in the New International Version's translation of verse 5: "I am making everything new!" It is not our 'worthiness' that carries us over the borders of death, not our efforts at renovation, particularly

116 Revelations 21:5.

117 Ibid. 
of ourselves that guarantees our journey out of time, 'into' eternity. No, it is God that has, is, and will be making everything new, being the Alpha and Omega, the Beginning and the End. ${ }^{118}$

As hard as it might be for us to believe, it is also not our technological achievements or breath-taking medical advances that would make such a 'new' world possible. The new earth does not emerge under a new heaven as the result of some or other brilliant computer programme. It comes from 'beyond', from 'above'. John sees the Holy City, the New Jerusalem, coming down out of heaven from God. ${ }^{119}$

It is God who acts. It is God who 'steps into' history. It is God who initiates our future.

It is God, and only God, who can make everything so new, who can recreate in such a comprehensive manner. There is an advertisement currently being repeated on television, endlessly it seems, about the renewal programme of a certain company, with the slogan: They did not change just one thing; they completely changed everything!

Well, that is wishful thinking - marketing overreach, at its best. Only God can 'completely change everything'.

Oh, of course, we can make some minor, or even major adjustments here and there; and often are forced to, 'adapt, or die.' Can we change ourselves fundamentally; can we renew ourselves completely? No.

Can we create the utopia that so many people have been dreaming about throughout the ages? Definitely not. Can we land people on the Moon and Mars? Yes, we can, and have, and will - but create a new earth? Impossible. Can we send people towards the outer borders of our solar system? Yes, we will, perhaps sooner than projected but create a new heaven? No, and again, no.

For this to happen - a new heaven and earth - God must speak out; God must utter a Word as creative as the one at the beginning of time: "It is good!"; a Word as salvific as the one amid time: "It is done!"; a Word as re-creative as the one at the end of time: "I am making everything new!"

This Word about the recreation of everything must have sounded like music in the ears of the early Christians. They were a persecuted minority, suffering unspeakable cruelties under Caesars like Nero and Domitianus. They were tortured and killed; they experienced poverty and hunger; they were stigmatised and excommunicated. It seemed as if the power systems of the world had taken complete control of them. 
How many tears did they not shed! Yes, how many tears have not flown on this planet called Earth? Tears upon tears, swelling up, forming a tsunami of sorrows. The Dutch theologian Jan Koopmans writes as follows:

Who can count the tears that have been shed in life and death, in sickness, joblessness, and war? Who shall soften the sorrow and comfort the bereaved? God. God has counted the tears and God keeps each and every one of them in God's thoughts [...] And, somewhere between time and eternity, while singing about the future, John says: God will wipe away all the tears from our eyes. But, let us understand this: not every expression of sorrow will be comforted in eternity. The tears of sinful rebellion and feigned remorse and sentimentality and hypocrisy will not be wiped away before God's throne. But the tears of God's children who cry out to God; the tears of true remorse, the tears of the lonely and deserted, of the humiliated and insulted, the shamed and persecuted - they will be no more.

The persecution of the early Christians was so intense that some considered giving up on their faith, even pondering the possibility of reverting to their former lives and beliefs. The voice from the throne spells out, in no uncertain terms, what the consequences of such an act would be:

Those who are victorious will inherit all this, and I will be their God and they will be my children. But the cowardly, the unbelieving, the vile, the murderers, the sexually immoral, those who practice magic arts, the idolaters and all liars - they will be consigned to the fiery lake of burning sulphur. This is the second death. ${ }^{121}$

These words of judgement deepen and accentuate the contrast with the alternative, namely the new heaven and earth. There could be no greater difference, no more radical divide, than between these two 'worlds' - the one is thrown back into (old) chaos; the other made completely new.

How on earth could we describe this 'new heaven and earth'? Tellingly enough, John himself offers only a few pen strokes, pointing out "what will not be there". ${ }^{122}$ Death will no longer be there. The transition from this world to eternity has finally come to an end. Suffering, sorrow, mourning, and pain - a type of summary of all the misery that characterised this old world - will no longer be there. The threatening powers will be gone. No more Nero or Domitianus, or ...

The chaos of evil, separation, and unsolved injustices will be gone, as surely as the sea, as a symbol of all this, will no longer be ${ }^{123}$ All forms of cruelty, all cruel people, and all cruel systems will not be found on the new earth, under a new heaven. Yes, God will wipe away all the tears from our eyes!

121 Revelation 21:7-8.

122 Revelation 21:1, 4.

123 Revelation 21:1. 
Eventually, John does venture some words of what will be there, but again, only with a few, broad strokes of his pen. There will be eternal security in the city of New Jerusalem. ${ }^{124}$ No more threats from enemies from without, or within. There will be eternal quenching of thirst and longing, also in the search for the meaning of life granted from the fountain of life, freely, and for free. ${ }^{125}$

Most importantly, as the summary and culmination of all the 'things' that will be there - God will be there. God's dwelling place will be amongst the people, and God will dwell with them. They will be God's people, and God will be with them and be their God, and they will be God's children. ${ }^{126}$ Who can picture this? Grace, upon grace, upon grace...

Utter nonsense! - some would say. Wishful thinking. Marketing overreach at its best ... for heaven? What proof do we have that the new heaven and earth will be as John describes them? How do we know that history is not headed towards nothing, or worse, towards the ultimate victory of the chaos threatening us for so long?

Or, just imagine: we pitch up for this great event, and the stage says: "He is gone!" The 'One' you believed was coming, or came, never was - and never will come. The outcome of that will be anything but frivolous.

So, where are we going? Towards nothing? Chaos? Eternal darkness? A consciousnessless void? Who says that all these descriptions in the Book of Revelations are not merely the hallucinations of a starved prophet on an island called Patmos, a long, long time ago? A new heaven and a new earth ... or the ramblings of a madman?

Well, 'proof' we do not have, but we do have a guarantee - which can only be accepted through faith. Our guarantee for what lies ahead is what lies behind. Our future is guaranteed by what God did in the past. On the grounds of what God did in the past, God will do what God will do in the future. God has already made mighty moves in the direction of the new heaven and earth. Incarnation, crucifixion, resurrection, ascension, and Pentecost are all part of the moves of God against the old world and the old order. They are especially God's guarantees for a new world and a new order.

When God says: "I am making everything new," it is not an empty phrase, but alreadyfulfilled words. It reads as present tense - based on the past tense. It is a recreation that is happening because it has happened. None other than God pronounces this past-and-present-tense-reality, this already-done-but-ongoing-deed from the throne: "... the old order of things has passed away ... it is done."127 It lies behind our backs, also in front of us. But it also is now. After all, someone who belongs to Christ is a new being. The old has passed away; the new has come. ${ }^{128}$ 
Earlier, I said that certain things 'will not be' there, in the new heaven and earth, and that certain things 'will be' there - as if in the future tense. It is, however, simultaneously present tense. This future is now, and now is this future.

Exactly for this reason, because of this praesentia futurum, we can and must make our moves against the old world order; we can and must protest in the Name of the Recreator against death and starvation, against tears and chaos and suffering. We are, after all, new beings, already part of God's recreation amid the old creation; we can see beyond time and death, and we do have glimpses of eternity.

We can and must share these glimpses of eternity, of God's tomorrow, with others, with all, today. The old order of things will pass away because it has passed away. We have been brought 'into' the new order, even though we still live in the old order. We celebrate the new order, and we protest against the old order. As follows:

There comes a day after all days on this old earth.

It is called the Day of the Lord, when God will bring an end to [...]

An end to the power of the powerful

over the fear of the weak [...]

An end to the crying of the children

because their mothers have no bread [...]

An end to the cries of the tortured

and the sadism of their tormentors [...]

An end to the fear of an atom war

and the scorching of God's good earth [...]

An end to the despising of the upright

and the evil intrigues of the liars [...]

An end to the persecution of God's children

and the mock courts of the night [...]

Then there will be inexpressible joy

and clear laughter will reign

and people will eat from laden tables

and will stammer with happiness

and we will be like people who are dreaming $[\ldots]$

Now already we dream of this glory

with wakened senses and in good hope

we prepare ourselves for this future

we withstand evil

and we proclaim God's salvation. ${ }^{129}$

129 Freely paraphrased from a poem by J. Hansen: After the dark comes a new morning. 
No, it is not our worthiness that carries us over the border from this world into eternity. There is One who was hailed as being worthy, worthy enough to hold the key that opens the door to our future in His hands. In the throne vision of John, we see and hear Him - the Lamb that was slaughtered. ${ }^{130}$

We hear thousands, yes, millions of voices - angels, the whole of creation, all that is in heaven and on earth and under the earth and on the sea, and all that is in them, cry out:

Worthy is the Lamb, who was slain, to receive power and wealth and wisdom and strength and honour and glory and praise!

To him who sits on the throne and to the Lamb be praise and honour and glory and power, for ever and ever ${ }^{131}$

This moment is where and when all wheres and whens, all instants and instances, are swallowed up, in the blink of an eye, as 'eternity'.

This moment is where the One who is coming and has come, will have come.

This is where we are going.

Amen! 


\section{Chapter 3 \\ GRACE: \\ TO KNOW THAT YOU ARE KNOWN, FULLY}

Where do we come from? Where are we going?

We have pondered these questions, obviously only touching the surface. There is still one question to reflect on: What (rather: who) are we?

This question can only be answered (admittedly, again only touching the surface), in the light of the previous two questions. Somewhere between where we come from and where we are going, we find the question: what and who are we?

This question can, of course, also be answered in many ways. If, for instance, we do not know where we come from, nor where we are headed, it does not matter what or who we are. If there is nothing and nowhere, i.e. nihilism, we can practically do anything, as it will not affect where we (did not) come from, and where we are (not) headed. As the saying goes: let us eat and drink and be merry because tomorrow we die; tomorrow our little moment between nothing and nowhere has expired. ${ }^{132}$

Or, we could try and compensate for the void behind and the abyss ahead, by excelling, striving for 'success', doing everything in our power to leave a 'legacy' behind. However, certain experiences on the borders of life make this difficult, and in the end, impossible - experiences like sickness, old age, and ultimately death.

Consider this scene: The Director of Company X sits behind his huge desk in his head office in the highest floor of his skyscraper. Around him, it is a beehive of activities. Clerks deliver messages, wait for orders; junior partners nervously hand in reports. The red telephone rings continuously. The Director, however, is in complete control, a picture of power, a dynamic giant between the other, smaller spirits, the heartbeat of his mighty Company $\mathrm{X}$.

Until he suffers a heart attack. Within seconds, the scene changes, and he is rushed off to the hospital. He is no longer in control but is being controlled. Motionless, he lies on his hospital bed, clamped down by the tentacles of medical machines and feeding drips. His vital signs are tentatively flickering on a screen. The sign on the door says No Visitors. The powerful man must have silence, must be kept still. His eyelids flutter open; he looks at the ceiling, he sees a fly there, circling around and around.

132 See also Paul's comments in 1 Corinthians 15:31. 
He is alone, with a fly.

Or, imagine this scenario: You were once the leading light in your field of expertise, not to speak about society. You travelled the world, met important and interesting people, and influenced countless lives. Some hailed you as their 'mentor'. Your space to move was boundless, and you organised your timetable to a tee.

However, speaking about time, yours ran out. First unnoticed and seemingly at an extremely slow pace, but then it felt as if someone had put a speed dial on your timetable, fast-forwarding it at an ever-accelerating pace. The day of your 'retirement' dawns, and you cannot believe 'how fast the time went by'. At first, you continue to move around and convince yourself that you are still in charge of your time(s). Soon you realise that this is irrevocably changing.

Your boundless space becomes smaller, eventually limited to a single room, or even a bed or wheelchair. You lose track of time. Those who hailed you as 'mentor' no longer has any memory of you. You no longer influence countless lives, but exist under the influence of a few people who decide for you. You no longer travel the world, meeting important and interesting people; instead, the world passes you by. You no longer have a voice in society, but society shuns you. You are no longer the leading light in your field of expertise.

On the contrary, you rage, you rage against the dying of the light. ${ }^{133}$

Or, let us imagine this - it is not that hard to do:

You can no longer rage against the dying of the light because it has been snuffed out. Darkness is all that remains and reigns. Your vital signs, flickering on a screen, go flat-line. You draw your last breath. You are taken to a mortuary. Your family, if you have some, collect your body. You are cremated or buried: your space becomes that of a coffin, six-feet-under. Your time is up. A line is drawn through all of your so-called 'successes' in life. Perhaps the memories of who you were and your endeavours will linger on for some time, in some cases even for ages, but ages are nothing (!) within the framework of cosmic time.

When you are gone, life goes on. It does not blink or stop for a second. People, also those who attended your funeral, rush back into the stream of societal happenstances. Perhaps some of them will come back to where you were buried, or where your ashes were strewn. Perhaps some will fondly recollect what you did and who you were. Most will race on in and with life, not realising: how small we are, how little we know.

Of course, all these scenarios express a certain morbidity about life. The question who or what we are seems at least irrelevant if the answer always seems to stumble over the hurdles of sickness, old age, and death. So, let us try another angle on this

133 An often-quoted phrase from the famous poem of Dylan Thomas, Do not go gentle into that good night. 
question, making use of the writings of the somewhat enigmatic author Nassim Nicholas Taleb, who argued that change, even change that might seem interruptive or disruptive at the time, could be embraced as the beginnings of new life. ${ }^{134}$

A candle might be put out by the wind, he says, but wind can also create a new fire - which he interprets as a symbol of new life. He poses the question of how we react to risks, to surprises, unexpected events, dramatic changes, shocks with far-reaching effects that rearrange the order as we know it. Sometimes, he says, some of these events might be completely strange, as the appearance of a black swan - and it is impossible to be prepared for such a strange happening.

This 'Black Swan Syndrome' reveals the hubris we often have concerning the limitations of our knowledge. Taleb even calls it an 'epistemic arrogance' - we overestimate what we know, and underestimate what we do not know. ${ }^{135}$ The reality is that we partially know now and that this partial knowledge is often challenged, or turned upside down - when, for instance, a Black Swan called COVID-19 makes an appearance amongst the white swans, as if from nowhere.

The question is, however, how we react to this Black Swan, i.e. how we 'see' it. For him, the challenge is to accept these strange twists and turns of history, to ride the wind, so to speak, so that you may be strengthened by this. We are fragile, Taleb would admit, but we must also learn the art of being 'antifragile' - a term that he coined himself - of seeing, and interpreting, and reacting to the inexplicable phenomena of life. ${ }^{136}$

I must confess, I like this take on things. It even sounds a bit like Kierkegaard's notion of seeing events in life differently, as instants as eternity. It at least spells out the beginnings of possibilities of being comforted in the face of life's catastrophes, even of being healed. The Black Swan of unexpected events might indeed be the disguise of the White Dove of Pentecost. The wind that snuffs out the candle, and extinguishes the last glimmerings of the dying light, might be the wind that kindles a new Light, might be the wind that carries us 'into' life.

For me, the notion of being antifragile is further deepened by the third part of the triad reflected on so far:

We do not know, fully; we will know, fully; we are known, fully.

'We are known fully'. Whether we are brimming with life, or looking at a fly from our hospital bed, or shrinking with age, or laid away in our 'final' resting place - we

134 Nassim Nicholas Taleb, The Black Swan. The Impact of the Highly Improbable, 136-140.

135 Ibid.

136 Obviously, these sentiments of Taleb could be criticised and misunderstood. Taleb is, for instance, not advocating a lifestyle of martyrdom-seeking. But he does call for a form of vision that sees deeper than the surface of life's events. 
are fully known. We are fragile, and yes; we can and should practise the art of being antifragile, without a doubt; but more than that - we are fully known whether we are fragile or antifragile.

Knowing that God knows us is grace. Knowing that God fully knows us is grace upon grace.

God knows us, from beginning to end, from the cradle to the grave. That is still not enough said. God knows us (present tense) before we came into bodily existence, and God knows us (present tense) after we leave this bodily existence behind. This 'meaning' is the highest of our lives: God wants to know us, i.e. wants to will us into existence. Why? Because God is love, and love is eternal. ${ }^{137}$

So, how do we express the fact that God fully knows us? I tried once to depict this by way of an artwork (Figure 10), painted in 2010. ${ }^{138}$

I used my own body to form an imprint on a coarse cloth, which seems to be nailed down to the rest of the canvass by a multitude of nails. The nails form the classic word INRI (Latin: Iesus Nazarenus Rex Iudaeorum, meaning Jesus of Nazareth, King of the Jews), seen above the head of the figure. The coarse cloth is reminiscent of the cloth in which Jesus was buried, and the meaning of the nails is obvious. The figure is stretched out as if on a cross with fragments or subtle forms of crosses in the background. With these features, I tried to depict something of the reality of the death of the Crucified - of the fact that he was not a disembodied spirit, but a body, a real body, just as we all have (rather, are) bodies.

Earlier I stated that our suffering had been taken up 'into' the Being of God, through the suffering of Christ. ${ }^{139}$ Our suffering has now become part of God's suffering; God's suffering has now become part of our suffering. This confluence of suffering(s) can only be seen, only be experienced in and through a body. In a body, the suffering of humans, and the suffering of God, dovetail. The White Dove of Pentecost underlines this: the Spirit has been poured out on all flesh, i.e. bodies. ${ }^{140}$

In times of suffering, this is our comfort: God's promises do not go away, do not leave us behind as lonesome bodies. God's promises can be trusted because it has a body. God embodies what God promises.

1371 Corinthians 13:7-8.

See also the discussion in Cilliers, Dancing with Deity, 55ff. This painting is currently displayed at the entrance of the Dutch Reformed Church, Welgelegen, Stellenbosch. 


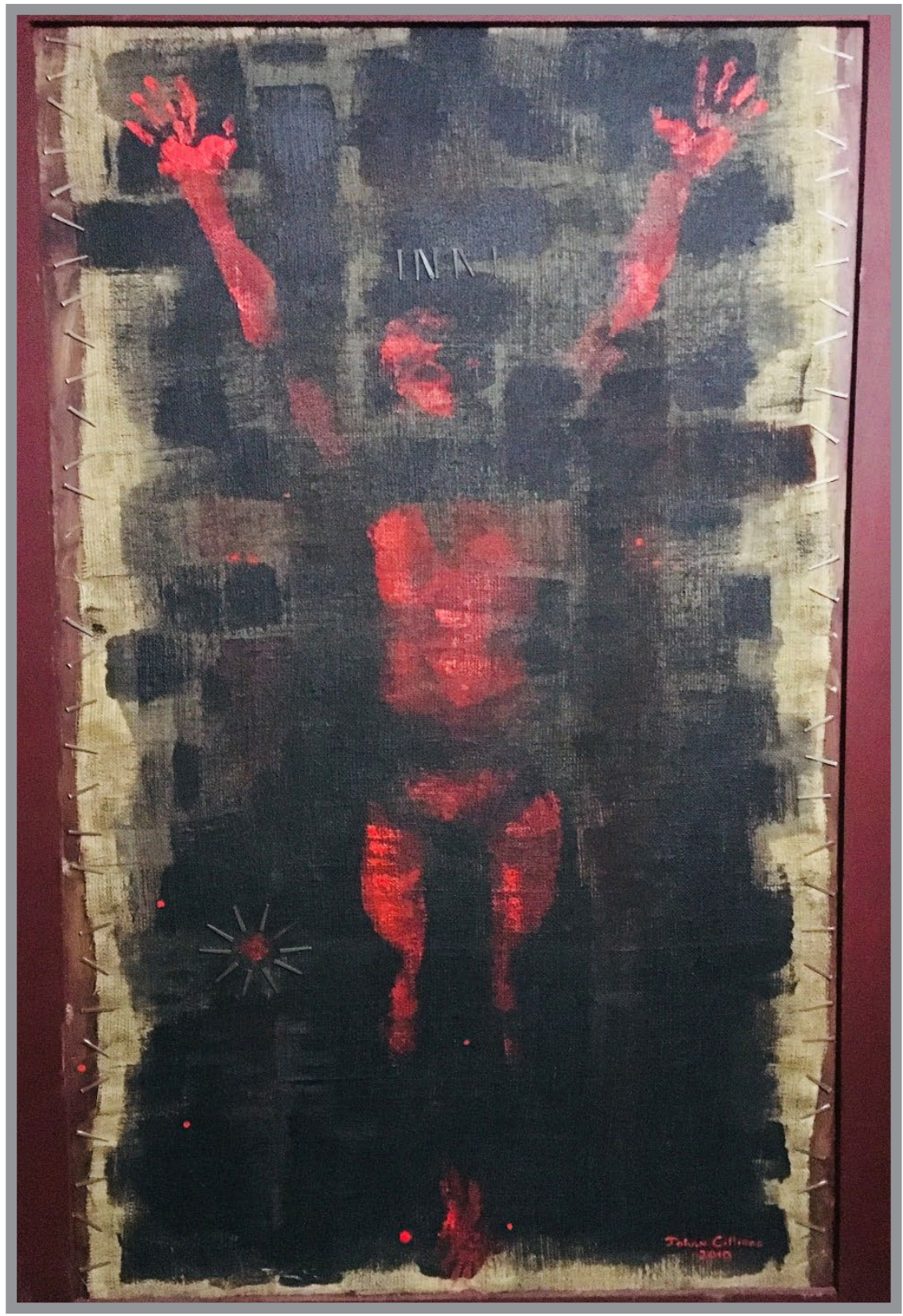

FIGURE 10: This very Body (2010) by Johan Cilliers. 
Søren Kierkegaard formulates this mystery as follows:

From the hour when by the omnipotent resolution of his omnipotent love he became a servant, he has himself become captive, so to speak, in his resolution and is now obliged to continue (to go on talking loosely) whether he wants to or not. ${ }^{141}$

There are signs of life (resurrection and victory) in the painting: the same nails that pin down the cloth cannot prevent it from being opened up to reveal the body inside; the nails also form a sun on the left side of the painting - as the symbol of life and righteousness, triumphing over the reality of these nails. The body, emerging from the cloth, formed and recreated against a background of fragmentation and darkness of chaos, is a type of prolepsis of resurrection. Central to the whole painting is the body, i.e. the embodiment of life and new life (hope). The artwork underlines the fact that life is not possible without the body, even and especially in its resurrected state.

Not only has our suffering entered into the Being of God so that it is now part of the Being of God; God's future has also entered into our bodies so that God's future is also now our future, as I said earlier. ${ }^{142}$ Our bodies now have a future. It is called resurrection.

For me, this depiction expressed the comforting truth that God knows about bodies. God's Son had a body. God knows my body, whether fragile or antifragile; knows my body in sickness and old age, in life and death. Therefore, the hands in the painting are stretched out towards the 'future' - also the future of this 'very body', now sick, old, fragile, dying, healthy or vital - stretched out in a motion of being taken 'into' life.

I remember once, when I was a student in Heidelberg, Germany, walking through the old part of the cemetery in Dossenheim - one of the suburbs of Heidelberg, a shortcut between where I lived, and the house of Rudolf Bohren, my PhD supervisor. It was a cold, wintry morning in 1981, and snow gathered on my green, corduroy cap. Halfway through the cemetery, my eye fell on a tombstone. I stopped and looked at the inscription:

\section{Unser Kleiner Sonnenstrahl.}

(1913-1919)

Ruhet in Gott.

141 Søren Kierkegaard, Philosophical Fragments/Johannes Climacus, 55.

See the discussion in Chapter 2. 
Our little ray of sunshine. Rest in God. It was the grave of a little girl who died a long time ago. She was only six years old. Her parents would also have died, long before I stood next to the grave of their child.

For some or other reason, it was one of the most emotional moments of my life. I did not know the girl, did not know her parents. I wondered about the 'meaning' of her life.

History has a way of swallowing up the common people. We just go away.

I wondered whether God knew about this girl, knew about her history, even knew her name? Although I will never forget the inscription - it is as if engraved into marble in my memory - I cannot remember her name, thinking back to that day in the cemetery.

Does God remember? Does God know? Does God know about the tiny baby who was buried in a karos (animal skin) in a shallow grave by her Koi mother, when Africa was still young? Does God know about the indistinctive little man who toiled lifelong in the office of a wealthy tycoon, and then died and was buried unceremoniously by the state, because he had no family? Does God know?

Ruhet in God, the inscription said - rest in God. I experienced a peace, a stillness, standing there in the snow in a foreign land in an old cemetery next to the grave of an unknown girl, a peace which I have difficulty to describe, even now, many years later.

A thought came to my mind, a text from the Bible, whispering: "Lord, You know me ... You have enclosed me behind and before, and laid your hand upon me." ${ }^{143}$ I have heard the whispering of this text many times since.

To be enclosed behind and before, yes, above and below - that is to be comforted beyond words.

My wife is a colourist: she loves to be surrounded by colour. Our home is anything but clinical white or drab grey. On the contrary, my wife habitually knits beautiful blankets for every room in our house - colour-coded, of course - her way of making meaning in view and out of her surroundings.

My favourite blanket can be seen in one of my favourite rooms, the space in front of the Karoo fireplace. Yes, there is a blanket there. When the fire's warmth is not enough, this blanket can be wrapped around you, behind and in front, over and below you, if you wish. For me, it symbolises (divine) comfort, made possible by grace upon grace. I have come home; I am at home.

143 Psalm 139:1, 5. 


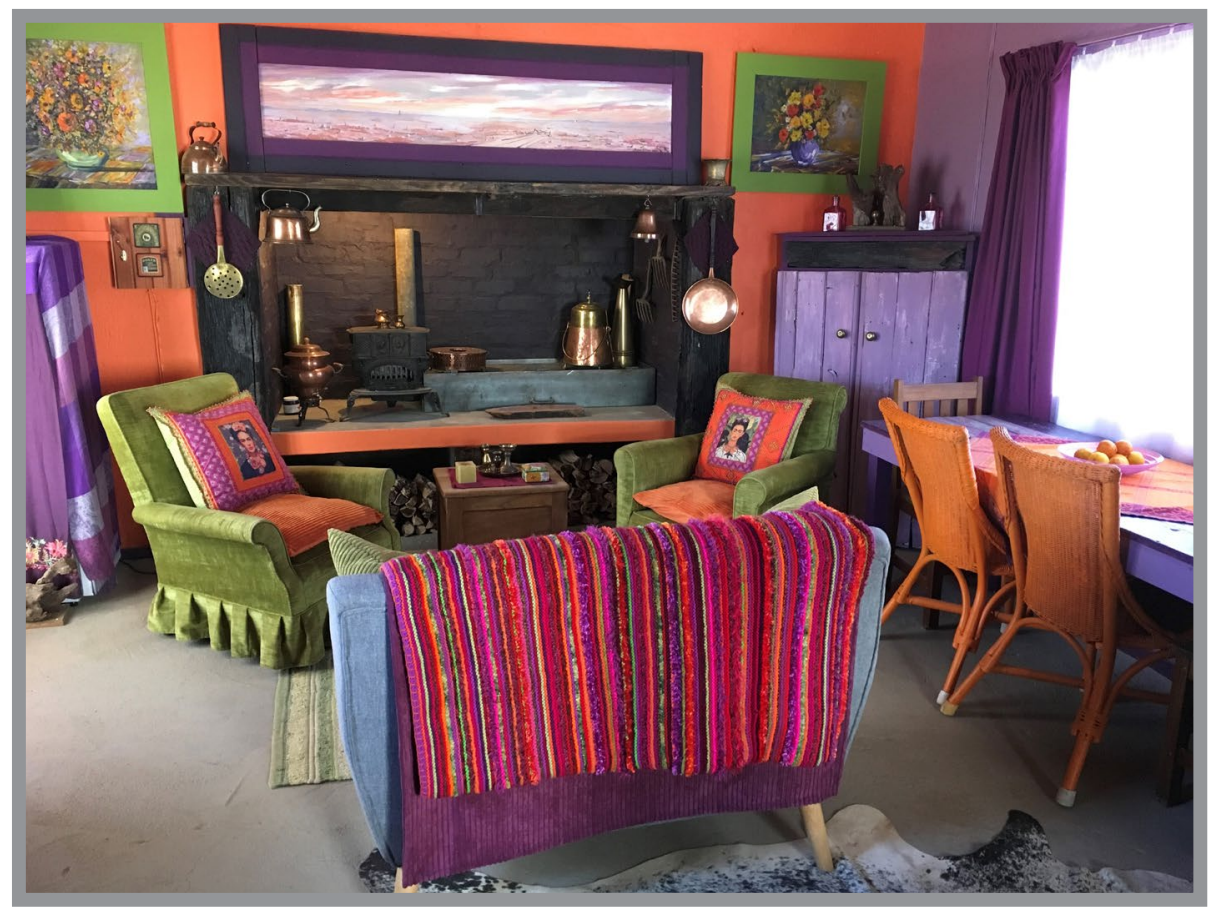

FIGURE 11: Blanket (2019) by Elna Cilliers.

Obviously, my wife is a creative and caring person - she raised our twins and coped with me. Enough said.

Well, perhaps the psalmist can say this even better, in his own, inimitable way. 


\section{MEDITATIVE INTERRUPTION \\ LORD, YOU KNOW ME \\ Psalm 139:1-3; 13-18}

In the Westminster Abby in London, one finds a remarkable Second World War memorabilia. It consists of four voluminous books containing the written names of about sixty thousand civilians who died during the airstrikes on London. One book always lies open on the altar, with a sharp light shining on the names on those two pages. Every day one page is turned so that all the names, book after book, are brought into the light and so-called back into memory.

This tradition - to call back into remembrance, by listing the names of people - one finds all over the world. In many cemeteries, the names of the dead from a catastrophe are often listed on a public plaque. People who died at sea, in air disasters, in the Holocaust, in tsunamis, in wars, in viral diseases - they are named, one by one. In South Africa, we see such a list of names of people who lost their lives in the struggle for democratic freedom when walking through the museum called Freedom Park, where this history is depicted.

In the Bible are several references to a book in which our names are written up, our whole history concentrated, and the mystery of our existence expressed. Psalm 69:29, for instance, speaks of a book of life in which the names of the righteous are written - a sentiment echoed in the Book of Revelations, where we hear that this book of life will be opened, with other books, in view of the judgement of the dead, young and old, according to what is documented about these people's actions or inactions. ${ }^{144}$

In Psalm 139:16, we also hear about a book, in a text that, on a personal level, has comforted me countless times, particularly in experiences of hopelessness and meaninglessness:

Your eyes saw my unformed body; all the days ordained for me were written in your book before one of them came to be.

With these words, the psalmist confesses that God knows everything about him, down to the smallest detail. That God sees straight through him, through the masks and smokescreens and barricades and flight-efforts. ${ }^{145}$ That nothing can be hidden from God, nothing under the sun.

144 Revelations 20:12, 15.

145 Cf. Psalm 139:1. 
So it is. God knows every cell and sinew of my body - yes, this very body - every bone and every tissue. God knows each thought before I think it; each word before I formulate it. ${ }^{146}$ Every hair on my head has been counted and computed in the heavenly realms. God knows my history, my background, my origins, my life's journey, my present and my future. God knows me before I was born, before I was woven together in my mother's womb. God knows where I will be tomorrow or ten or twenty years from now. In short: there is not a single thing in all my being and existence about which God does not know everything.

This knowledge of God is not abstract. Not a type of heavenly 'know about' or 'take note of' or 'have heard of' knowledge. No, God's knowledge of us confirms that we belong to God. God knows us so fully that we belong to God. Between us, the created, and God, the Creator, exists an intimate relationship. After all, God is the Potter; we are the clay. ${ }^{147}$

'Sin' could be described as the breaking-up of this relationship, the severing of this connection, as the unthinkable (im)possibility that alienation could take place between God and us; that we (try to) flee away from the very One from whom we received the gift of life.

We cannot, as the psalmist also discovered, 'escape' from God's presence, cannot flee from God's Spirit, cannot hide away from God - not in the heaven (or in the church), or in death (the cemetery), or by packing our bags and travelling to the east or west, or into the darkness of night. ${ }^{148}$ Nowhere.

Why would we run, and why would we hide? For how can the creature say to the Creator: I do not need you? How can the clay rebel against its moulding in the hands of the Potter? Impossible. That is what 'sin' is - the impossible possible.

God did not, could not, leave it at that. God refused to let go of us. God turned the impossible possible scenario around. Because, for God, all things are possible. ${ }^{149}$

The story of the New Testament is God changing the impossible into the possible, once again. For God sends God's Son in the form of a human, to confirm that God has property rights on us. This Son is formed in the mother's womb to underline that we, also formed in this way, belong to God, our Formator. We do not belong to ourselves. In a sense, we are confirmed as belonging to God twice. God's Son dies. He breathes his last breath on the Cross, before being resurrected. In this way, we are not only made but also made new; not only created but also recreated. 
"All the days ordained for me were written in your book before one of them came to be," the psalmist confesses. He knows: God has a plan with my life. I was not born for nothing. Not by chance. Not by luck or accident. Not simply because of a cosmic or biological confluence of small blobs of living plasma.

Oh, of course, there are days we feel exactly like this: when nothing makes sense anymore; you are overwhelmed by the daily toils and responsibilities of things cluttering your table and filling up your agenda. You become so carried away in the stream of everyday life, that you cannot see the bigger picture of God's plan for you. When you keep on banging your head painfully against so-called blind fate, then you should know: the mystery of my life's journey is resolved in God's book. Then you must keep on repeating to yourself, as a refrain of faith: "All the days ordained for me were written in your book before one of them came to be."

When your plans do not work out, or when life takes on a different course than the one you hoped for, or when your plans and ideals for your children and grandchildren do not come to fruition, and you are anxious about them, then this is our only comfort, in life and death: "All the days ordained for them, as for me, were written in God's book before one of them came to be."

Of course, one could ask: does this mean that God literally 'controls' everything, from the great and catastrophic things like death and war to the minutest details of our everyday lives? Is it God who decides whether I get a parking spot right in front of the supermarket, or whether I must drive six blocks further on? Is it God who determines what colour shirt or dress I will be buying? Whether I bump my toe against the curb? Is God small enough to be drawn into such mundane events?

One could have a variety of opinions about this. You could, for starters, decide that 'God' has got absolutely nothing to do with any of these everyday things - you could write God completely out of the picture. What therefore happens to you, is simply the intersection of several circumstances, the positive or negative overlapping of the coordinates of time, place, and happenstances. What you experience is nothing more, and nothing less, than the logical consequences of luck, accident, fate or ill fate, or, if things go well, the logical results of your careful planning, of your focused drive to reach all your goals in life, and to succeed. Such a view might lead you into sublime euphoria - if things go 'according to plan' - or, dump you into the deepest pit of depression - if things 'go south'.

As an opposite possibility, you could write God so completely into the picture, that humans of flesh and blood, humans with their moral responsibilities and neurological processes of decision-making, are negated. Then you become a mere marionette, or an elongation of God, whose acts seamlessly become the acts of God. Such a view can take on terrifying dimensions. You could justify your acts as being God's acts; you can label your enemies as God's enemies; you can write about your guilt as simply the misunderstandings of other, less informed people. Then you can intimidate your 
adversaries with the highest ace available in psychological warfare, namely to believe and to state that your enemies are warring against God; and: God is on my side.

There is a third way to think about this, an approach only understood from a perspective of faith. One that takes the relationship between God and humans seriously, but indeed as a 'relationship'. Then you accept, on the one hand, that people are fragile; they do not fully know; they make mistakes; they are not walking duplicates of God. On the contrary, they tend to contradict and resist God's will and acts. That the negative things that happen in life, therefore, cannot be put on God's account, but on ours. Wars and violence and death are the consequences of our misdoings. Or, to put this in the immortal words of the dying son, Markel, in Dostoevsky's The Brothers Karamazov, spoken to his mother: "Each of us is guilty before everyone, for everyone, and I more than others."

On the other side, this perspective of faith also comforts us with the knowledge that God does not abandon us, or leave us to deal with ourselves - that would indeed be catastrophic. No, God can transform even the negative things that we are responsible for, into good things; and yes, God does remain present in the minutest detail of our lives. We cannot say something is too personal and too 'small' for God. God did count the hairs on our heads. God does fully know what every hour of our lives holds - with all the events therein, big or small, comforting or disastrous. God does know about the filled-up parking spaces, and the sharp-edged curbs. God knows, fully.

God is big enough to be small enough to be interested in our minutest and most mundane doings. God does not force God on us, does not take the decision about the colour of our shirt or dress out of our hands, but God is closer to us than our shirt or dress (Martin Luther). God has a relationship with us, which means: God is my Help and Support, also in the small things of life, but God is not the Recipe for Success for all 'my' ideals.

Our responsibilities are not taken out of our hands, and we do not become soulless pawns in God's grand game of chess. On the contrary, God incorporates us, with our responsibilities, in the game of life. The fact that God has a plan does not mean that we should be without a plan. The comfort to know that God knows before, and ahead of us, does not make us irresponsible - rather responsible.

Perhaps the classic metaphor, used by the old exegete AW Tozer, helps us here. We are like people on a passenger ship, he says, en route from one harbour to another. The route has been planned already, carefully, and in detail. The destination is set. The people on board, however, have space to move about; encouraged to do so. They are not behind bars, not chained down in their cabins. Their lives on board, their comings and goings, are not restricted in a draconian manner. They can eat and sleep, play on the deck, take in a suntan. They can live under God's sun before God (coram deo). 
They know: "All the days ordained for me were written in your book before one of them came to be."

Each day of this journey belongs to God.

My destination is certain.

God's Book says so. 


\section{CONCLUSION}

\section{The art of meaning-making}

In the introduction to this book, I ventured a preliminary description of the space where the quest for meaning could take place as follows:

The quest for meaning takes place in the interplay between the negotiations of not knowing fully, the hope of knowing fully, and the good news that we are known, fully.

I also put it in other (more 'theological') terms:

The quest for meaning is nurtured in and through the intersections of hermeneutics (the art of interpretation), hope (the art of expectation) and healing (the art of being comforted).

Let us now, briefly, revisit these thoughts in the light of what we have said so far.

First, finding 'meaning' does not equate acquiring complete knowledge. The fact is, we do not know everything about the basic questions of life, i.e. where we come from, who we are, and where we are going. We do know a lot, and our knowledge, particularly about these questions, is increasing rapidly. The fields of cosmology and astrophysics, anthropology and psychology, technology and futurology, for instance, are constantly opening up new possibilities, making innovative discoveries.

Even now, we do not know, less even understand, the deepest mysteries of this cosmos and our place (i.e. the 'meaning' of our lives) in it. Theologically, we are part of humanity, also seeking knowledge about the mysteries of life, with the added dimension - we speak, or profess to speak, about the Ultimate Mystery, namely God. We do not know everything about God and the creation, about the origins of our existence. Nor do we know everything about our future, about the outcomes of our existence. We do not know everything about how we should be living in the present, about the modes of our everyday existence. We do not know - that is, or should be, part and parcel of the confession of faith of all theologians, let alone believers.

This reality - that we do not know it all - calls for a deeper sensitivity and consideration when we speak about people. We should be slow to speak, and even slower to judge. We should resist the urge to stereotype, and stigmatise, and eventually exorcise.

It also calls for a certain humility when we speak about God. We should resist our tendency to proclaim 'The Truth' as if we have it in our grip. We should be careful not to construct fixed and fixated God-images. Many of these images are constructed to fit into our agendas. 
Of course, we cannot do without God-images, likewise as theologians; we are constantly called upon to create God-images. We are simultaneously called to dismantle them. We are called to create God-images, to break them down; to imagine God-images, so that we can re-imagine them; to set up God-images, knowing that these images cannot be controlled, secured, or encapsulated in time. ${ }^{150}$

All these processes imply the art of interpretation, i.e. hermeneutics. Hermeneutics is not about duplication of certain 'truths' to understand them better, but about the interpretation of these truths, as it pertains to life, be it as expressed in texts, or events, or visual art, or sound. This interpretation of life never happens in an 'objective' manner. We always interpret from our subjective points of view and, in this sense, we always 'make' meaning. Interpretation, therefore, always implies appropriation (i.e. interpreting) 'reality' in a way that 'makes sense to us.' 'Meaning' is not something that exists 'out there'; it always happens, or is created, in and through our endeavours to find meaning. Again, Victor Frankl: "The meaning of life is to give meaning to life."

As we pointed out earlier, this is surely a serious issue, but simultaneously playful. We play, we 'tinker' about with possibilities; we are bricoleurs, appropriating what we experience in life in the hope of discovering new knowledge, and in the expectancy of being 'surprised by joy'. 151

This would be the first mind-switch needed for those who go off on a search for meaning: it is and will remain, at least for now, a search, a process, a way to travel, a path of pilgrimage. Martin Luther once echoed these sentiments:

This life is not piety, but becoming pious; not health, but becoming healthy; not being, but becoming; not rest, but practice. We are not yet, but we are becoming; it is not yet done or finished, but it is in progress and happening. It is not the end, but it is the way. Everything is not yet glow and glitter, but everything is being purified. ${ }^{152}$

Second, searching for 'meaning' does not equal wandering around in an eternal labyrinth of not-knowing. On the contrary, we do live in the expectancy of fully knowing. If this were not the case, we would have been not unlike a hamster, forever running on a treadmill, seemingly busy, but going nowhere. We are going somewhere, and this knowledge colours our behaviour and instils hope in us. We know - although we do not exactly know how - something is in the air. We sense (we could call it faith) that Someone is surrounding us, taking us forward, 'into' the future. We are not hamsters without hope.

150 See my discussion in Cilliers, Timing Grace, 61ff.

151 Cf. the title of the book by C.S. Lewis, Surprised by Joy. The Shape of my Early Life.

152 In the original: "Dieses Leben ist keine Frömmigkeit, sondern ein Fromm-Werden. Keine Gesundheit, sondern ein Gesund-Werden. Kein Wesen, sondern ein Werden. Keine Ruhe, sondern ein Üben. Wir sind es noch nicht; werden es aber. Es ist noch nicht getan oder geschehen, es ist aber im Gang und im Schwang. Es ist nicht das Ende, es ist aber der Weg. Es glüht und glänzt noch nicht alles, es reinigt sich aber alles." Martin Luther, Pastoral Writings. Auslegung zu Philipper 3: 13. 
I remember once, sitting at the breakfast table with Rudolf Bohren, my Swiss-German $\mathrm{PhD}$ mentor, and he told me of the following incident in his life: he was sitting with his wife, Ehrentraut, at the same breakfast table one morning, and she looked out the window and said: "Rudolf, it is going to rain." He also looked out the window, saw the clouds gathering, and found no reason to disagree with his wife's assessment of the weather forecast for the day.

But, Bohren said, this announcement about the possibility, even probability of rain did not affect him, as he planned to spend the rest of the day in his study, working on the book he was writing at the time. After a few hours, the clouds dispersed, and some blue skies peered through. Bohren and his wife decided to go for a walk, as they often did, in the neighbouring Dossenheim forest. They were ardent walkers, putting up a stiff pace, and covering quite a distance in a relatively short time.

When they were some distance from home, the clouds gathered once again; the skies darkened, the air became pregnant with the possibility, or indeed the probability, of rain. Ehrentraut looked at the sky, and repeated the same words that she said that morning at the breakfast table, the same sentence construction, the same use of grammar - the same, yet different: "Rudolf, it is going to rain." This time, however, the announcement of rain affected Bohren, and his wife, inescapably. This time they were not under the shelter of a roof. This time it coloured the way they behaved - with them turning around, and walking even faster, keeping an eye on the sky. The announcement at the breakfast table met with indifference, the one under the sky with a vivid expectation.

When Bohren came to this part of his story, he had a twinkle in his eye, and he said something like the following. "You see, so often we are, literally, theologians-in-ourstudies; we sit at our desks, and we write beautiful books, we think out wonderful theological constructions, and we are quite content. We need to be brought out, under the air, we need to see the sky, we need to expect the raindrops to fall on our faces, any minute now, and we need to hasten in our journey..."

For me, this narrative has become a metaphor of how to do theology, or better: how to hope. The future is not far off; it is here. Eternity is not somewhere in the distance; it is close by, filling up the air that surrounds us. All we need to do is look, and to see this instant as eternity.

In the quest for meaning, we should know that we do not know; that we are on our way; and while we are on this way, we should also keep on looking at the skies, knowing that what is to come, already is. The raindrops of grace upon grace, are hanging heavily from the roof of heaven, pregnant with promise, in fact, already dropping.

We do, however, also need a third mode of knowledge if we are to come closer to 'meaning'. 
Sometimes, the road on which we travel seems too long and becomes too much. Sometimes, we feel the need to stop walking and sit down. Sometimes, we are looking for a bench on the side of the road to sit and be.

This moment is where the third mode of knowledge comes to our aid and helps us to heal. For, while searching for meaning, we are comforted by the fact that 'we are known', now, fully - even if, and exactly because, we are en route to knowing fully, and presently still in a state of not-knowing fully.

There exists an inescapable interconnectedness between these three modes of knowing, not only fostering the quest for meaning but indicating the space within which it takes place. While searching for meaning, we are continuously drawn into this space: from not knowing, to knowing, to being known. Implying that, although we have the calling to search for meaning, in the hope of attaining a better understanding of meaning, there are times in which we should also celebrate the meaning that we have found. We need not only search for meaning but also celebrate meaning.

Or, to put in differently: there are times when we may know that, although we have not yet reached the full knowledge of meaning, that meaning has reached us. The movement is then changed around - we are now known; we now become the space within which meaning is instilled, and I would hasten to add, as I did throughout this book: this happens through grace upon grace.

I would suggest that meaning is something that 'happens', continuously so, in the overlapping and integration of these three modes of knowledge that we have spoken about, and which structure this book. Perhaps we could illustrate this as follows:

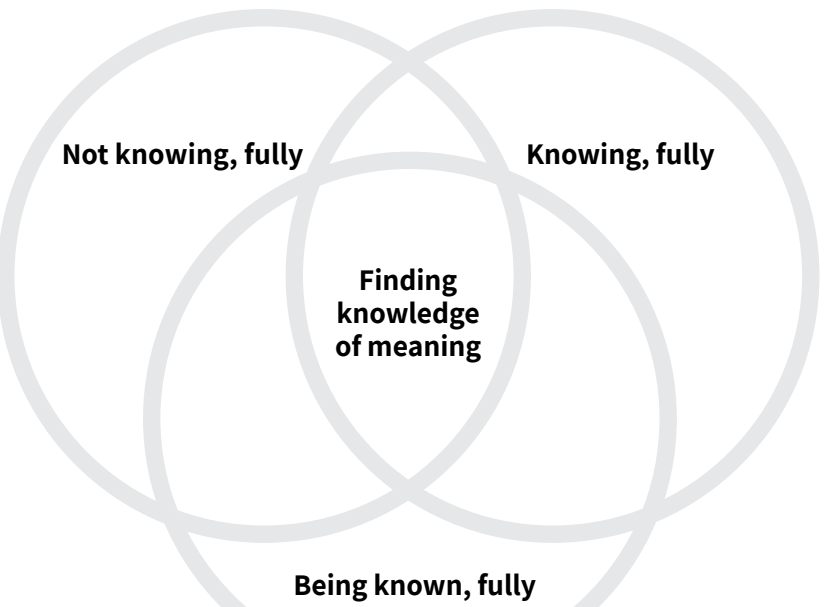

FIGURE 12: Integration: Finding the knowledge of meaning. 
Let us now, for the sake of further clarification, hypothesise as follows: what would happen if one, or more, of these modes of knowledge, were taken out of the space of overlapping, i.e. if the inherent integration of these modes were disturbed? If, for instance, the mode of not-knowing fully were seen as the only mode, separated from the rest? Then, I would postulate, nihilism will be the logical consequence - "let us eat and drink, because tomorrow we die".

It could also lead to frenzied activism, trying to create some sense of meaning through treading that treadmill. If you are not on the treadmill, you are out, chasing the wind. However, neither nihilism nor activism can, in my opinion, foster meaning. On the contrary, wind-chasers have difficulties getting a grip on meaning.

What would happen if the mode of hoping for full knowledge, i.e. the future, becomes separated from the rest? Then one could fall prey to a form of futurism that implies escapism. Then you no longer search for knowledge, or meaning-throughknowledge, in this life but only aim at the life 'beyond'. Then you are more interested in 'life after death', than in 'life before death'. However, I would postulate again: this would go completely against the grain of the gospel - which speaks of God entering 'into' this life, in the Person of Jesus. Then you would be like the apostles, looking up at the clouds in which Jesus was 'taken away', not realising that this ascension does not nullify the incarnation, but brings it to fruition. ${ }^{153}$

Cloud-watching is not necessarily wrong. Bohren and his wife, Ehrentraut, for instance, looked at the clouds, but then they moved, fast. Their act of cloud-watching affected their behaviour, ignited in them a sense of expectancy, determining their stance. For them, it gave new meaning to the notion and their habit of 'going for a walk'

Futurism and escapism - standing still and peering at the skies can, in my opinion, also not foster meaning. On the contrary, cloud-watchers could lose out on life and, in the process, the joy of discovering meaning. Cloud-watchers could have difficulties to dance, for the joy of life, to the music of grace. They might trip over their toes.

What if the mode of being fully known is taken out of the integration with the rest? Then, I would postulate once more: the result would be a form of quietism - not escaping from life this time but closing in on your own life. Then you no longer take part in the human quest for knowledge and meaning, no longer live in the expectation of knowledge and meaning, but you are circling yourself all the time.

If you are circling yourself all the time, you do not have time for others. Then you do not understand the meaning of self-sacrifice and service, for the sake of others. ${ }^{154}$ Then you miss out on the meaning of life, simply because you do not give meaning to the life of others. Then you are saying 'I' all the time and in such a way that 'meaning'

153 See Acts 1:9-11.

154 See also the discussion in Chapter 2. 
ends up with 'I' and 'I' alone. But 'I' is no island. If you are on an island, you do not understand what 'we' means. 'I' also means 'we'. As I said earlier, 'we' have been given the gift, the grace, of community.

'We are here now'

In classical theological terms, this circling around yourself, continuously paddling around your own island, would be called pietism. Then, if you are not busy paddling around your own island, you are sitting on the bench all the time - also the bench next to the road, if not the one in front of your cosy fireplace - covering yourself with your religious or moralistic little blanket, trying to warm yourself against the chills of doubt and the fatigue of pilgrimage. Then, you are waiting to be warmed up, to be comforted; forgetting that others also need warmth and comfort.

Again, in my opinion, quietism and pietism - devoid of self-sacrifice and service for the sake of the 'we' - render no real possibility for meaning-making; ends up in melancholia, perhaps taking the circle back to nihilism.

Neither wind-chasers, nor cloud-watchers, nor bench-sitters have a good chance to find or celebrate the meaning of life. For that, they need to be integrated into the overlapping of knowledge modes, as suggested above.

Wind-chasers need to acquire the art of interpretation, that is to realise that life consists of fragments that must (playfully) be juggled but can never be fully fitted together.

Cloud-watchers require the art of expectation, that is to realise that the 'future' is not somewhere or sometime in the distance, but continuously breaking into the present - for us to discern with hope.

Bench-sitters must re-learn the art of healing, that is to understand that we are known by One other than ourselves and that this knowledge is liberating beyond words; liberating in a manner that we cannot achieve by trying to do this by ourselves, for ourselves; liberating in a manner that we are taken out of ourselves, for others. 
Again, by way of illustration:

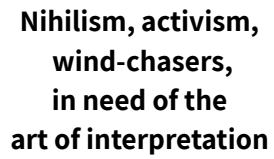
Futurism, escapism, cloud-watchers, in need of the art of expectation

\section{$\longleftrightarrow$ bench-sitters, in need of the art of healing}

Quietism, pietism,

FIGURE 13: Disintegration: Losing the art of meaning.

I speak about the 'art' of interpretation, expectation, and healing, and I do this intentionally. These 'arts' can, in my opinion, flourish within an aesthetical life approach, as the introduction to this book suggested. It is by way of aesthetics that we can juggle interpretations; can imagine presences of the future-in-the-now; can express our gratitude and celebrations for the gifts of life, and the discoveries of meaning, albeit fragments thereof - in a way that surpasses words.

'Now, here I am,' at the end of this book, where I started. It has become clear that the recognition that I am, here and now, in no way represents or offers a quick fix to life's problems, or a shortcut to finding the meaning of life, or a form of escapism from reality. It is not meant as a slogan for yet another self-help scheme, or a feel-good enterprise.

On the contrary, it presupposes a process, a life-long journey, struggling with and within the tensions and challenges and frustrations of not knowing, of the experiences and glimpses of full knowledge, and the inexpressible comfort of being known. Saying I am, here and now, does not come cheap - neither does grace, for that matter.

Immanuel Levinas wrote movingly about this recognition that I am, here and now. He calls it a subjectivity as an identity, articulated from the start as an accusative: This is me, and here I am (me voici). ${ }^{155}$ Being me is the best place to be, but also 
exposed, often frightfully so. Being me implies having a desire (désir), not the same as having a need (craving for satisfaction), or merely a functional effect of being. It is about yearning and longing; existential unrest, an 'earnest search and quest'. It could also be described as honourable powerlessness, or, when life takes on unpredictable twists and turns, even a condition of existential imbalance. ${ }^{156}$

We do not know everything, and sometimes the Black Swan comes swimming into our tranquil pond. Then it is time to look up, into our 'being me' in Christ, which is our future. Then it becomes time to say: Now, here am I - being comforted in ways I could not do myself, or for the sake of others.

So, 'now, here am I' at the end of this book, where I started.

Now - I have been given the gift, the grace of time, of a moment, of moments.

Here - I have been given the gift, the grace of space, of spaces.

Am - I have been given the gift, the grace of life, of existence.

I - I have been given the gift, the grace of being me, of individuality.

We - have been given the gift, the grace of community.

We are here now.

I am here now.

Grace upon grace. 


\section{BIBLIOGRAPHY}

Babette's Feast. 1987. Film. Directed by Gabriel Axel. Norway: Danish Film Institute.

Blixen, Karen (pseudonym Dinesen, Isak). 1958. Babette's Feast. In: Anecdotes of Destiny. New York: Random House.

Boeve, Lieven. 2012. The shortest definition of religion 1-3. The Pastoral Review, 5(3):4-9; 5(4):4-9; 5(5):18-25.

Boime, Albert. 2008. Gauguin's D’où venons-nous? Que sommes-nous? Où allons-nous? Millenarianism and Necromancy in Fin-de-Siècle France. In: Revelation of Modernism: Responses to Cultural Crises in Fin-de-Siècle Painting. London: University of Missouri Press. 175-176.

Breton, André. 1993. Conversations: The Autobiography of Surrealism. New York: Paragon House. 230-236.

Büchner, Ludwig. 1869. Der Mensch und seine Stellung in der Natur in Vergangenheit, Gegenwart und Zukunft: Woher kommen wir? Wer sind wir? Wohin gehen wir? Leipzig: Thomas Publishing Company. 33ff.

Campbell, Charles \& Cilliers, Johan. 2012. Preaching Fools: The Gospel as a Rhetoric of Folly. Waco, TX: Baylor University Press. 45-48.

Cilliers, Johan. 2019. Timing Grace: Reflections on the Temporality of Preaching. Stellenbosch: African Sun Media. 33ff, 61ff, Chapter 2. https://doi.org/10.18820/9781928480235

Cilliers, Johan. 2017. Seeing, sighing, signing - contours of a vulnerable homiletic. https://doi.org/10.7833/115-0-1281

Cilliers, Johan. 2016. A Space for Grace: Towards an Aesthetics of Preaching. Stellenbosch: African Sun Media. 1ff. https://doi.org/10.18820/9781920689940

Cilliers, Johan. 2013. Between Fragments and Fullness: Worshipping in the in-between spaces of Africa. HTS Theological Studies/Teologiese Studies, 69(2):1-6. https://doi.org/10.4102/ hts.v69i2.1296

Cilliers, Johan. 2012. Dancing with Deity: Reimagining the Beauty of Worship. Wellington: Bybel Media. 55-60, 187, 216ff, Chapter 2.

Cilliers, Johan. 2011. Fides Quaerens Pulchrum: Practical Theological Perspectives on the Desire for Beauty. Scriptura: International Journal for Bible, Religion and Theology in Southern Africa, 3(108):257-268. https://doi.org/10.7833/108-0-1

Cilliers, Johan. 2004. The Living Voice of the Gospel: Revisiting the basic principles of preaching. Stellenbosch: African Sun Media. 230ff. https://doi.org/10.18820/9781919980287

De Chardin, Teilhard. 1977. Christianity and Evolution. London: Collins.

Dutch Reformed Church. 2001. Liedboek van die Kerk: begeleiersboek. Wellington: Reformed Church Publishers.

Edwards, Ruth B. 1988. XÁPIN ANTİ XÁPITO乏 (John 1.16) Grace and the Law in the Johannine Prologue, 1-14. Journal for the Study of the New Testament, 32:3-15. https://doi.org/10.1177/0142064X8801003201 
FitzGerald, Edward.1859. The Rubáiyát of Omar Khayyam. 1st American Edition. Boston, MA: Houghton, Osgood \& Company.

Frankl, Victor E. 1947. Ein Psycholog erlebt das Konzentrationslager. 2nd Edition. Wien: Verlag für Jugend und Volk. 56-60.

Gehlen, Arnold. 1986. Urmensch und Spätkultur. Philosophische Ergebnisse und Aussagen. Wiesbaden: Aula. 66ff.

Hart, David B. 2003. The Beauty of the Infinite: The Aesthetics of Christian Truth. Grand Rapids, MI: WM. B. Eerdmans. 15.

John. 2001. The Bible. English Standard Version. Wheaton, IL: Crossway / Good News Publishers. 1:16-17.

Josuttis, Manfred. 1998. Identität und Konversion. In: Dietrich Stollberg (ed). Identität im Wandel in Kirche und Gesellschaft. Göttingen: F.S. Richard Riess. 117-118, 126.

Kierkegaard, Søren. 1985. Philosophical Fragments/Johannes Climacus. Translated by Edna \& Howard Hong. Princeton, NJ : Princeton University Press. 55.

Kierkegaard, Søren. 1967. The Concept of Dread. Princeton, NJ: Princeton University Press. 77-81.

Lévi, Eliphas. 1854. Dogme et Rituel de la Haute Magie. (Transcendental Magic: Its Doctrine and Ritual). Translated by Waite, Arthur E. 1896. https://bit.ly/2BHVaUI; https://bit.ly/3dLlXO0

Levinas, Immanuel. 1978. Une réligion d'adultes. In: Het menselijk gelaat: essays van Emmanuel Levinas. Translated by Otto de Nobel \& Ad Peperzak. Baarn: Ambo/Anthos. 24-41.

Lewis, Clive S. 1955. Surprised by Joy. The Shape of My Early Life. New York: Harcourt Brace.

Luther, Henning. 1992. Religion und Alltag: Bausteine zu einer Praktischen Theologie des Subjekts. Stuttgart: Radius-Verlag. 160-161, 167-172, 175, 180-182.

Luther, Martin. 2016. Pastoral Writings. The Annotated Luther Series, 4:43. Philadelphia, PA: Fortress Press.

Luther, Martin. 1883. 1521, Andere, Grund und Ursach. Die Weimarer Ausgabe, 7(336):31f. Weimar: Böhlau-Verlag.

Luther, Martin. 1883. 1518, Disputatio Heidelbergae habita. Die Weimarer Ausgabe, I(354). Weimar: Böhlau-Verlag.

MoMA Learning. 2020. Bicycle Wheel: Marcel Duchamp. https://mo.ma/2XvfTDJ

Nietzsche, Friedrich. 1973. Die fröhliche Wissenschaft (1882). Nietzsche (KGA), 5(2):201.

Pattison, Stephen. 2007. Seeing Things: Deepening Relations with Visual Artefacts. London: SCM Press. 1. https://doi.org/10.2752/175183408X328389

Picasso, Pablo. 1946. La Joie de Vivre painting. Antibes, France: Musée Picasso.

Rossouw, Hennie W. 1984. Die Sin van die Lewe. Cape Town: Tafelberg Uitgewers. $27 \mathrm{ff}$.

Schoeman, Chris. 2013. The Historical Karoo: Traces of the Past in South Africa's Arid Interior. Cape Town: Zebra Press. 8-9.

Seekamp, Kristina. 2005. Unmaking the Museum: Marcel Duchamp's Readymades in Context: Bicycle Wheel. Tout-Fait: The Marcel Duchamp Studies Online Journal. https://bit.ly/2MEIuAd

Serres, Michel. 1987. Statues: The Second Book of Foundations. Paris: Editions François Bourin. 226. 
Shackelford, George \& Frèches-Thory, Claire (eds). 2004. Gauguin Tahiti: Exhibition Catalogue. Boston, MA: Museum of Fine Arts Publications. 168.

Taleb, Nassim N. 2007. The Black Swan. The Impact of the Highly Improbable. New York: Random House. 136-140.

The Adding Machine. 1969. Film. United Kingdom: Associated London Films \& Universal Pictures.

The Bible. New International Version (NIV). 1978. Colorado Springs, CO: Biblica.

The Bible. New Living Translation (NLT). 1996. Carol Stream, IL: Tyndale House Publishers.

The Museum of Modern Art. 2020. Art and artists. Marcel Duchamp. Bicycle Wheel. https://www.moma.org/collection/works/81631

Thomas, Dylan. 1952. The Poems of Dylan Thomas. New York: New Directions Publishing.

Van Ruler, Arnold A. 1975. De meeste van deze is de Liefde. Het hart omvat de dingen en heeft ze lief. Den Haag: Van Stockum. 83.

Weyel, Birgit. 2007. Predigt und Alltagskunst. Wilhelm Genazino und der poetische Blick auf das Leben. In: Gräb, Wilhelm, Hermann, Jörg, Kulbarsch, Lars, Metelmann, Jörg \& Weyel, Birgit (eds). Religion - Ästhetik - Medien. Band 2. Ästhetik und Religion. Interdisziplinäre Beiträge zur Identität und Differenz von ästhetischer und religiöser Erfahrung. Frankfurt: Peter Lang GmbH. 209-211.

Wikiquote. 2020. Monty Python's The Meaning of Life. https://bit.ly/3h2o6qD

Wilson, Earl. 1968. How Small We Are, How Little We Know. Song. Glamorous-Music Inc. 